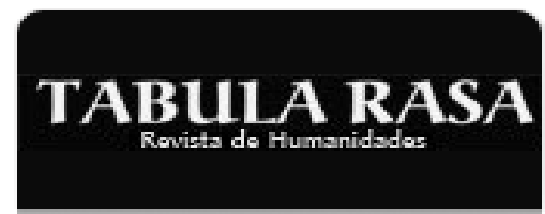

Tabula Rasa

ISSN: 1794-2489

info@revistatabularasa.org

Universidad Colegio Mayor de Cundinamarca Colombia

Mudimbe, Valentin Y.

EN LA CASA DE LIBIA: UNA MEDITACIÓN

Tabula Rasa, núm. 11, julio-diciembre, 2009, pp. 141-193

Universidad Colegio Mayor de Cundinamarca

Bogotá, Colombia

Disponible en: http://www.redalyc.org/articulo.oa?id=39617332008

- Cómo citar el artículo



- Número completo

- Más información del artículo

- Página de la revista en redalyc.org

Sistema de Información Científica

Red de Revistas Científicas de América Latina, el Caribe, España y Portugal

Proyecto académico sin fines de lucro, desarrollado bajo la iniciativa de acceso abierto 


\title{
EN LA CASA DE Libia: UNA MEditaCióN ${ }^{1}$ In The House of Libya: A Meditation NA CASA de LÍBia: uMa MEditaÇão
}

\author{
VALENTIN Y. MUDIMBE ${ }^{2}$ \\ Duke University, Durham, USA \\ vmudimbe@duke.edu
}

Recibido: 17 de marzo de 2009

Aceptado: 29 de mayo de 2009

Resumen:

Pueda que de los mitos griegos, Libia, en sus dimensiones simbólicas, es menos reconocido en la imaginación contemporánea. Sin embargo, sin narrativas de Libia, sería difícil inducir un número de lecciones de los cuales algunos de los peores aprietos han podido ser regulados. Por ejemplo, entre los descendientes de Libia se encuentran Cadmos y Europa, Jocasta y Oedipus, Antigone y Ismene. Libia no tiene entrada autónoma en un número de diccionarios populares de analectas míticas y religiosas. Esa ausencia es sorprendente. Una de las compañeras de Poseidón, el dios de mar, en la línea genealógica de la casa de Argos, Libia es una descendente directa de Zeus e Io, y, a través de Ephanus y Memphis, la abuela de Aegyptos y Danaos. Un personaje eponímico, Libia activa múltiples líneas figurativas. El nombre de la madre de Agenor y Belus también sirve para designaciones geográficas. En esta maniobra esta puesto como símbolo polisemico en las narrativas históricas y míticas. La interferencia pasó al latino, y esta bien atestiguada en los clásicos. Palabras clave: transcultural, mito, verdad, filosofía griega, espacio colonial, orden cosmológico.

\footnotetext{
${ }^{1}$ Este artículo es producto de la investigación del autor sobre filosofía friega y espacio colonial. Con extrema gratitud reconozco a las siguientes personas que, en diversas capacidades, han acompañado esta meditación: Andrew Apter, Diane Ciekawy, Paul de Meester, Pierre-Philippe Fraiture, Lia Haro, Dan Orrells, Erin Post, David Schultz y Henri Vogel. Es un placer expresar mi aprecio a Trip Attaway por su aptitud y dedicación.

${ }^{2}$ (Nota del Editor) Valentin Y. Mudimbe es profesor Ivey White de literatura en Duke University, Durham, Estados Unidos. Recibió su doctorado en filosofia de letras de la Universidad de Louvain en 1970. En 1997, recibió su doctorado Honoris Causa de la Universidad de Paris VII. Antes de llegar a Duke, enseño en las universidades de Louvain, Paris-Nanterre, Zaire, Stanford y en el Haverford College. Ha publicado unos setenta artículos, tres colecciones de poesía, cuatro novelas y varios libros sobre lingüística aplicada, filosofía y ciencias sociales. Su más recientes publicaciones incluyen L'Odeur Du Père (1982), The Invention of Africa (1988), Parables and Fables (1991), The Idea of Africa (1994), y Tales of Faith (1997). Es editor de The Surreptitious Speech (1992), Nations, Identities, Cultures (1997), Diaspora and Immigration (1999) y editor de una próxima enciclopedia de religiones y filosofía africana. También fue secretario general de SAPINA (Sociedad de Filosofía Africana en América del Norte) y editor asociado con Robert Bates y Jean O'Barr de Africa and the Disciplines (1993). V.Y. Mudimbe también es miembro correspondiente de la Académie Royale des Sciencs d'Outre Mer, Brussels; un miembro de por vida de la Société Américaine de Philosophie de Langue Française; y miembro de la Society for Phenomenology and Existential Philosophy y del World Institute for Advanced Phenomenological Research and Learning. Sus intereses centran alrededor de fenomenología y estructuralismo, con un enfoque en la lógica de narrativas mitológicas y la práctica del lenguaje. Fue presidente de la junta de filosofía africana y es presidente de la junta del Instituto Internacional Africano, SOAS, Universidad de Londres. Regularmente da clases de geografía antigua griega, fenomenología francesa, y temas africanos.
} 


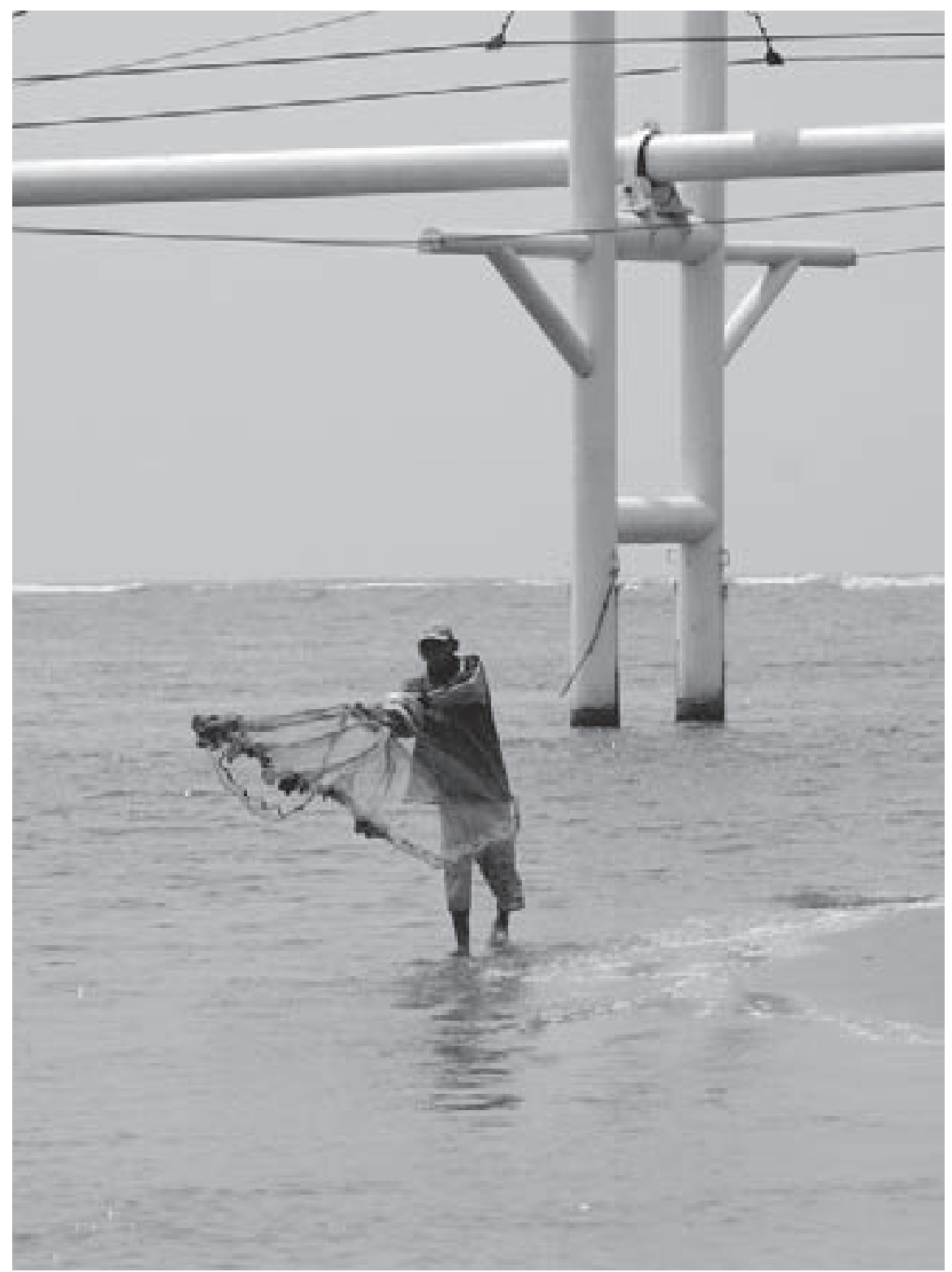

PUEBLO VIEJO

Fotografía de Laura Cecilia Chaves 
Abstract:

From Greek myths, Libya, in its symbolic dimensions, may be one of the less recognized in contemporary imagination. Yet, without narratives on Libya, it would be difficult to induce a number of lessons from which some of the worst predicaments have come to be regulated. For instance, among the descendents of Libya are Cadmos and Europa, Jocasta and Oedipus, Antigone and Ismene. Libya has no autonomous entry in a number of popular dictionaries of mythical and religious analecta. The absence is remarkable. One of the partners of Poseidon, the god of the sea, in the genealogical line of the house of Argos, Libya is a direct descendent of Zeus and Io; and, through Epaphus and Memphis, the grandmother of Aegyptos and Danaos. An eponymic persona, Libya activates multiple figurative lines. The name of the mother of Agenor and Belus serves also geographic designations. In this maneuver it stands as a polysemic symbol in historical and mythical narratives. The interference passed into Latin, and is well attested in classics.

Key words: transcultural, mythos, truth, Greek philosophy, colonial space, cosmological order.

Resumo:

Dos mitos gregos, a Líbia, em suas dimensões simbólicas, pode estar entre as personagens menos reconhecidas na imaginação contemporânea. Ademais, sem as narrativas sobre a Líbia seria difícil introduzir uma série de ensinamentos a partir dos quais algumas das piores situações têm sido reguladas. Por exemplo, entre os descendentes de Líbia estão Cadmo e Europa, Jocasta e Édipo, Antígona e Ismênia. Líbia não tem uma entrada autônoma em vários dicionários populares míticos e religiosos. A ausência é notável. Líbia é parceira de Poseidon, o deus do mar, na linha genealógica da casa de Argos, e descendente direta de Zeus e Io. É avó de Egito e Danão, através de Épafo e Mênfis. Como uma personagem epônima, Líbia movimenta múltiplas linhas figurativas. O nome da mãe de Agenor e Belo serve também como denominação geográfica. Deste modo, se apresenta como símbolo polissêmico nas narrativas históricas e míticas. A interferência passou para o latim, e é bem atestada nos clássicos.

Palavras chave: transcultural, mito, verdade, filosofia grega, espaço colonial, ordem cosmológica.

Para Martín Bernal

Sobre la estatua de Zeus en Olimpia

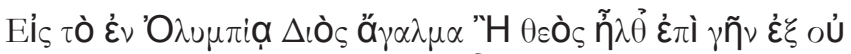



— W.R. Paton, ed., The Greek. Anthology (1916:16, 81). ${ }^{3}$

${ }^{3}$ The Greek Anthology es una colección de 6.000 poemas griegos cortos. Tratan de una gran variedad de temas en varios estilos, y fueron compuestos por unos 300 poetas que cubren un milenio de la cultura griega. Varían en extensión y calidad, pero incluyen algo del mejor verso escrito en griego. La mayoría de los poemas viene de un solo manuscrito, el llamado "Antología Palatina», y fueron montados en el siglo X. Otros fueron recogidos en el siglo XIII por el monje Planudes (nota del Editor). 
O Dios vino del Cielo a la Tierra para mostraros Su imagen, Fidias, o vos fuísteis a ver a Dios. ${ }^{4}$

En la geografía y la mitología, Libia ( $\Lambda$ ĩßòn) representa una serie de enigmas.

${ }^{4}$ Las ediciones griegas que se han usado pertenecen a la Loeb Classical Library, esta es una serie de libros, publicada Harvard University Press, que contiene los trabajos más importantes escritos en griego clásico y en latín. Presentan el texto original y una traducción bastante rigurosa. Esta serie de volúmenes (que ya cuenta con varios cientos) fue concebida y fundada inicialmente por James Loeb. Los primeros volúmenes fueron editados por T. E. Page, Edward Capps y W. H. D. Rouse, y publicados por William Heinemann en 1912 (nota del Editor). tampoco por haber sido durante siglos también el nombre de todo el continente africano. «Africam Graeci Libyam appellavere [...]», escribe Plinio El Viejo en Naturalis Historia $(5,1)$. Odiseo, ya antes, dio fe de la complejidad de la figura. Libia ( $\Lambda$ ĩن̀ $)$, in 4, 85 —designa la región occidental de Egipto; y, antes en el mismo texto $(4,42)$ - , se ha usado para aludir a todo el continente de manera manifiesta.

De otro lado, desde los mitos griegos, Libia, en sus dimensiones simbólicas, puede ser uno de los menos reconocidos en la imaginación moderna. Sin embargo, sin narrativas sobre Libia, sería difícil inducir varias lecciones a partir de las cuales han llegado a regularse algunos de los peores predicamentos. Por ejemplo, entre los descendientes de Libia están Cadmos y Europa, Yocasta y Edipo, Antígona e Ismene (Tabla 1). Libia no tiene una entrada autónoma en varios importantes diccionarios de analectas míticas y religiosas. La ausencia es notable. Una de las esposas de Poseidón, dios del mar, en la línea genealógica de la casa de Argos, Libia es descendiente directa de Zeus e Io; y, a través de Épafo y Menfis, abuela de AEgiptoos y Dánao. Persona eponímica, Libia activa múltiple líneas figurativas. El nombre de la madre de Agenor y Belus sirve también como designación geográfica. En esta maniobra representa un símbolo polisémico en las narrativas míticas e históricas. La interferencia entró al latín, y está bien documentada en los clásicos.

\section{En la BIBLIOTHECA ( $\left.\beta \iota \beta \lambda_{\imath}-\theta \dot{\eta} \varkappa \eta\right)$.}

Un punto de origen, sintagmático y en asociación, Libia debe conceptualizarse en lo femenino, en el griego y el latín antiguos. Respondiendo a las expectativas sobre su verdad sobre la cuestión griega de cómo explicar la guerra contra los no griegos, Heródoto identifica a Libia con la parte norte de África, y se centra en

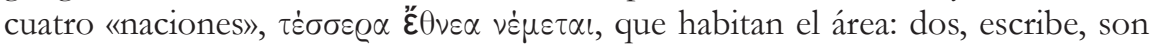
autóctonas, los libos en el norte y los etíopes en el sur; dos son colonizadores tardíos, los fenicios y los griegos. Concluye delimitando una estructura compuesta

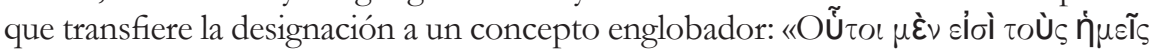



Tabula Rasa. Bogotá - Colombia, No.11: 141-193, julio-diciembre 2009

ISSN 1794-2489 



vívidos panoramas de la cuenca del Mediterráneo. Diodoro recuenta la historia del universo, desde la génesis de las divinidades hasta la culminación de la historia, la misma práctica que reclama para sí, en la escritura de la historia de las historias. Dedicado principalmente a Etiopía, la región sur de Libia, y el mar Índico, su tercer libro cumple varias funciones. Incluyen la calidad de de la cronología de Diodoro; $\mathrm{y}$, desde su perspectiva, una lectura de las narrativas fundacionales en el génesis u origen de los dioses, los mitos y la historia, la geografía y las colonizaciones.

Libia, como Egipto, nombra una divinidad, una región y a sus habitantes. De Heródoto en adelante, escribe Diodoro $(1,37)$, han estado ligados al Nilo, o

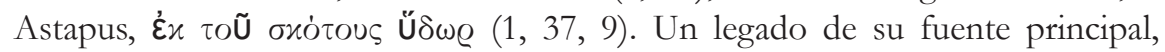
Agatárquides de Cnido, la ambigüedad del vocabulario atañe en su mayor parte a la parte occidental de Egipto, y al sur de Etiopía. En la larga especulación de su primer libro, a propósito de la «inflamación» y «caída» del Nilo en relación con el solsticio y el equinoccio, fiel a un conocimiento establecido, Diodoro hace referencia a la geografía física. Así, por ejemplo, a partir de la autoridad de Heródoto, la siguiente referencia a la geografía:

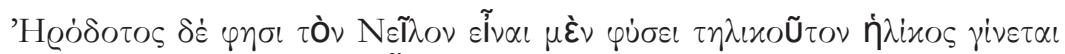

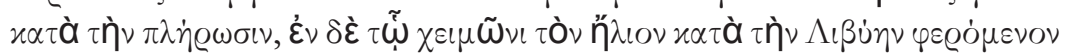



Como lo afirma, en su cúspide, el volumen del río Nilo es natural; sin embargo,


Nilo una gran cantidad de agua hacia sí.

Un uso diferente de la palabra se observa en los primeros párrafos del mismo libro. Dos divinidades, Libia y Poseidón son invocadas en la expansión de las colonias egipcias. Para Babilonia, por ejemplo, los colonizadores fueron dirigidos por Belus, hijo de Libia y Poseidón (I, 28). Con la referencia, Diodoro reformula una larga memoria que es testigo de una interacción entre el mito y la geografía, una conjunción constante bien ilustrada por Ramin en Mythologie et géographie (Les Belles Lettres, 1979). Puede afirmarse con certeza que a lo largo de la historia cultural grecorromana, Libia es sinónimo del continente y de sus gentes. Ejemplos bastantes convincentes de esto se encuentran en Vida de Apolonio de Tiana, de Filóstrato el Ateniense. La entrada al libro cinco es sobre las columnas de Hércules. Omitiendo las fábulas relacionadas con Hércules, escribe, comienza con un registro descriptivo impecable: «Los extremos de Europa y la frontera de Libia en un desfiladero de sesenta estadios de ancho [...]. La extremidad de Libia, que lleva el nombre de Abinna [...]»:

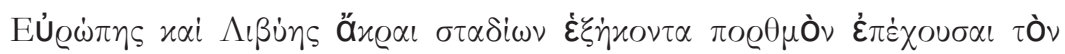

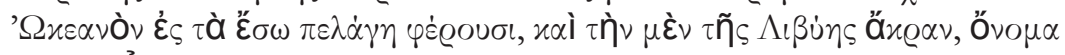
$\delta \dot{\varepsilon} \alpha \dot{U} \tau \tilde{\eta}{ }^{\prime} A \beta \iota \nu \nu \alpha$ (Cap. 1). 
En este mismo capítulo, se hace mención de un río llamado Libia. Pero el adjetivo

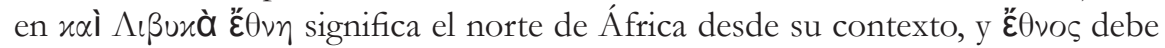
traducirse como nación.

La tabla 1 presenta la familia mítica de Libia, como puede deducirse de varias fuentes griegas. Las reconstrucciones modernas incluyen Women of Classical Mythology: A Biographical Dictionary, de Robert E. Bell (Oxford University Press, 1991); el Dictionary of Classical Mythology, de Pierre Grimal (Blackwell, 1985); el The Oxford Dictionary of Classical Myth and Religion, de Simon Price y Emily Kearns (Oxford, 2003); y, la quinta edición de Classical Mythology (Longman, 1995) de Mark P.O. Morford y Robert J. Lenardon. La estructuración de la tabla corresponde básicamente a la de Pierre Grimal. Puede modificarse con consultas de varios admirables «Quién es quién en la mitología griega y romana» de ayer y de hoy. La confiable presentación crítica de J. Bremmer, ed., Interpretations of Greek Mythology (Londres, 1987), es ahora un clásico, junto con la adaptación del The Routledge Handbook of Greek Mythology (2003), de H.J. Rose, de 1928. Sin duda, la autoridad de todas estas fuentes se remotan a Scriptores rerum mytbicarum (Bode, 1968).

El proceso de esta reflexión consider la cuenca del Mediterráneo pues ha sido durante milenios un espacio intercultural creado por un mar interno que conecta a Eurasia con África. Testimonios, de diferente origen y naturaleza, han suministrado argumentos sobre su transculturalidad. Pormenores de los mitos, especulaciones y las ciencias, no siempre sometidos a idénticos criterios de verdad-falsedad, han atestiguado una diversidad que se resiste a una reducción a un único encasillamiento; y, al mismo tiempo, informa sobre la singularidad de una historia común.

\section{Tabla 1}



Tabula Rasa. Bogotá - Colombia, No.11: 141-193, julio-diciembre 2009

ISSN 1794-2489 
Desde Libia, ninfa y mito, divina y humana, puede considerarse lo que el mito nombre, y su relación con la geografía y la historia. Libia es una cuestión griega, al menos de la manera como puede enfrentársela en tres ángulos complementarios: la realidad de un oíxoupévn (oikumenê), la constitución de importantes casas desde la norma de la migración; y, representaciones de una ley fundacional: el don de la vida como otro nombre para el don del miedo. Heródoto, y Píndaro (aprox. 518 BC - después de 446), en Pythian Ode I, se hacen eco: es mucho mejor despertar envidia que lástima.

El oỉxoupèvin (oikoumenê), o, el mundo habitado, según la Meteorologica de Aristóteles (362 26$)$, incluye la cuenca del Mediterráneo misma, así como las áreas limítrofes de Etiopía, India, Escita. En De Mundo (392 26), abarca únicamente la limitada geografía de Libia, Asia y Europa. Nombres de tierras, estos son nombres de legenda. Así, la designación Libia, dice Heródoto (4, 45), habría provenido de una nativa; Asia, del «dador del fuego», esposa de Prometeo (o de Asies, el hijo Manes). En cuanto a Europa, insiste Heródoto, rechazando un posible origen fenicio, nadie sabe «de dónde tomó su nombre ni es claro quién

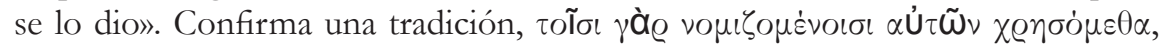
«usaremos los nombres establecidos por el uso».

La Geography del alejandrino Claudio Ptolomeo, escrita alrededor del 160 A. de C. anuncia una continuidad. El oikoumenê $(7,4)$ es un inmenso continente contenido entre paralelos que van por todo Thulē en el norte, y Anti-Meroē en el sur; es decir, más allá del ecuador. Tres continentes interconectados, dice el título descriptivo de la edición de Princeton (2000) fijada por J. Lennart Berggren y Alexander Jones:

Por lo tanto de los tres continentes, Asia está conectada con Libyē por el estrecho en Arabia, que también separa el mar Mediterráneo de la Bahía Arábica, y por la tierra desconocida que rodea al Mar de la India. Y [Asia] está conectada a Europa por el estrecho de tierra entre el lago Maiōtis y el Océano Sarmatiano donde cruza el río Tanais. Libyē está dividida de Europa sólo por los Estrechos [de Hēraklēs], y no está en sí misma adherida [a Europa] en absoluto, sino sólo por medio de Asia, pues [Asia] está unida a ambas, bordéandolas a ambas por el este (2000:109).

De la biblioteca de Heródoto a la de Apolodoro, compilada en el siglo I o II, las narrativas ponen a los dos hijos gemelos de Libia, Belos y Agenor, como fundadores en esta geografía. Las primeras reglas del reino de Egipto; el segundo, padre de Cadmos y Europa, un rey fenicio, reina sobre Sidón o Tiro. La genealogía vincula las áreas geográficas. Un espacio común corrobora las historias de una descendencia. Las variaciones que pueden verse entre Eurípides y Heródoto son efectos de una interminable exégesis. Son motivos en la complejidad de las imágenes transculturales y los signos arquetípicos. La cápsula romana de un mare nostrum subsume una realidad cultural empírica. 
La génesis de las casas reales detalla sus relacines con un tiempo humano en el que los nietos de Libia - AEgiptoos, Dánao, Cadmos, Europa, etc.-encarnan una violencia original. Un mito de un miedo perpetuo puede explicar tanto una rivalidad por el patrimonio como la justificación de soberanías autónomas de casas interrelacionadas en el parentesco de sangre. Estas casas reales se instituyen en forma simultánea, en un reconocimiento de la emigración y la conquista como un derecho a acceder al poder.

a. Egipto, hijo de Belo y Anquinoe, hace huir a su hermano Dánao, y se convierte en rey de Egipto. Es padre de cincuenta hijos y epónimo de Egipto.

b. Dánao, hermano de Egipto, sale del país después de ser derrotado por su hermano. Bajo la protección de Atenas, emigra a Argos con sus cincuenta hijas. Después de una competencia con Gelanor, el gobernante reinante, es hecho rey. Dánao invierte la saga de su ancestro Ío, que había sido llevada a Egipto.

c. Cadmos, hijo de Agenor y Argiope (o Telefasa), hermano de Europa, desposa a Armonía. Es fundador de Tebas en el continente que pobló con los «hombres plantados» o Espartos.

d. Europa, la única mujer de esta generación de fundadores de la ley, es hija del fenicio Agenor. Amada por Zeus, dio a luz tres hijos, entre ellos Minos a quien transmite el don que había recibido de Zeus para su protección, el «talos», hombre de bronce. Se convirtió en el guardián protector de Creta. Zeus desposó a Europa con Asterio, rey de Creta. Esta mujer de cuna asiática, escribe Heródoto $(4,45)$, nunca vino a esta tierra que los griegos ahora llaman «Europa».

Madre y abuela, entre lo divino y lo humano, Libia es símbolo en las mismas historias que la comentan. Según otras fuentes, ella era hermana de Telégonos, quien desposó a Ío. En ocasiones, es hija de Ío. A sus dos hijos, Agenor y Belos, en ocasiones se añade Lelex. De esta forma, la casa de Megara aparece entre las de los Argivos y los Cadmios. También entre sus hijos, se encuentra ocasionalmente a Bursiris el egipcio, Enyalius-Ares, Fénix y Atlas. En raras referencias, Libia es esposa de Tritón, la divinidad marina con cola de pez. Un esquema muy estructurado convierte a Libia en hermana de Asia, Europa y Tracio, todos ellos hijos de Océanus. En este reparto eponímico, están representados todos los aspectos del Mediterráneo.

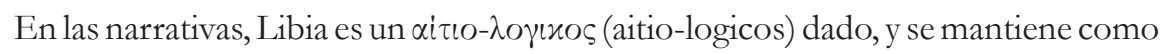
una aitia, acusación y culpa, en la responsabilidad negativa y positiva. Genetriz, Libia asume una genealogía y el destino de sus nietos, origen y generación, 
justicias y agravios. Ella condensa en las narrativas griegas una declaración divina y su lúgubre cruzamiento humano. La «invención» de una topografía inaugura la confrontación en una necesidad, el don de la vida como un don del miedo, y en su forma inversa. En varios textos antiguos, Libia y Poseidón son «una explicación» de fábulas sobre tal origen.

La génesis de las cuatro casas coincide con la institución de una nueva ley. Brota de la violencia mejor ilustrada en la casa de Tebas (Tabla 2), a través de conflictos que aún obsesionan los paradigmas psicológicos. Claude Lévi-Strauss ha sugerido su código fundamental en Structural Antbropology (Basic Books, 1974): de un lado, una sobrevaloración, o una subestimación de las relaciones de consanguinidad; y, del otro lado, una excesiva afirmación, o negación, de una autoctonía.

Para un análisis más detallado de la creación de Libia, las conferencias de Georges Dumézil y Claude Lévi-Strauss en estudios comparativos pueden inspirar una lectura sintomática que acomoda fuentes heterogéneas y da testimonio a la vez de la atmósfera (la de la materia así como la de los autores que participan en ella) y de su dinámica. Es importante señalar, contra lo que pueda resultar de The Greeks and the Irrational de E.R. Dodds (University of California Press, 1951), un título inquietante para una decodificación rigurosa de los enunciados religiosos de la antigua Grecia, que lo que lo orienta sirve como clave para el capítulo de Giulia Sissa y Marcel Detienne sobre Homero en The Daily Life of the Greek Gods (Stanford University Press, 2000). Es un interrogante sobre cómo designar el corpus de historias sobre todas estas divinidades: «نiteratura o antropología?» La tensión entre géneros, logos y muthos, literatura y antropología, y lo que representan, explica el estudio de Dodds, pues explica la perspectiva de Detienne y Sissa: «En Grecia, los dioses nacieron en la tierra» (2000: 4).

\section{Tabla 2}



Tabula Rasa. Bogotá - Colombia, No.11: 141-193, julio-diciembre 2009

ISSN 1794-2489 


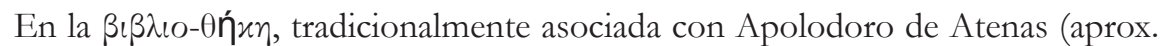
180- después del 120 A.de C.), la tensión supone la historia de una antropología, y su literatura. Su matriz geográfica es la cuenca del Mediterráneo. Es posible que Apolodoro no sea el autor de la $\beta \iota \beta \lambda \iota-\theta n ́ x \eta$, como lo señaló Albin Lesky en $A$ History of Greek Literature (Hackett, 1966: 787), y ese no es el problema aquí. El problema, se refiere a una genealogía y su importancia. Un monumento sincrético, probablemente escrito en el siglo I o II, la Bibliotheca repite los ciclos del Mediterráneo que, según Tucídides $(2,41)$, hicieron de Atenas la maestra de Grecia; y, en la cuenca del Mediterráneo, a Grecia, una referencia indisputable, en el lenguaje de los Epodi de Horacio (2, 1, 28): «quia Graecorum sunt antiquissima quaeque Scripta vel optima, etc.».

Un símbolo, la Bibliotheca representa una inscripción en su propia historia, la de una ambición por reflejar una historia universal. De igual modo, la Bibliotheca insinúa una medida de su indización a un espacio cultural. Coincide con la historia del mar Mediterráneo grecorromano. Pese a tal dependencia, los exégetas aún dan explicaciones sobre sus señales con el fin de entender las paradojas de los inicios, así como incluso predicamentos actuales. Por ejemplo, al leer Uncovering the Ancient World (Oxford, 1986) de HVF Winstone, cómo enfrentar la singularidad de la idea griega en una cuenca multicultural en el Mediterráneo, y toman en cuenta la disposición a la verdad transmitida en sus mitos transculturales, y los hechos empíricos de la Bibliotheca. Otra línea se referiría a las formas de valoración de dos tendencias actuales. Por un lado, desde la percepción de la filosofía de la ciencia en la primera parte del siglo XX, está la magistral obra sobre la ciencia griega de Abel Rey, en la serie de la Bibliothèque de Synthèse Historique, publicada en París por La Renaissance du Livre: 1. La Science orientale avant les Grecs, 2. La Jeunesse de la science grecque, 3. La Science hellénistique. De otro lado, desde los impulsos sincréticos de la Bibliotheca de Apolodoro, cómo recordar lo que afirman los volúmenes Black Athena de Martin Bernal con «las raíces afroasiáticas de la civilización clásica», y la diferencia que proyectan en la representación actual de las sociedades y culturas del Mediterráneo. En la elaboración de perspectivas y los puentes que ellas reconsideran entre estas culturas, así como en la misma práctica discursiva que interroga sus límites, la biblioteca griega tiene un estatus de pernigilium, es decir, derecho a sí misma, y una exención de sí misma. En nuevas mutualidades, su tradición procesa un desafío permanente a su idea de lo que significa la antigua Grecia, y a la noción de historia universal de la que reclama ser ejemplo. Para el título de su libro sobre «Contiendas en la historia cultural del helenismo», un tema bien circunscrito, Simon Goldhill invoca una pregunta sobre el valor simbólico de los griegos y la razón que sostiene, Who Needs Greek? (Cambridge, 2002). ¿No quiere decir Goldhill exactamente lo que la pregunta plantea: «¿quién no necesita a los griegos?» Thomas Cahill lo abordó como imperativo cultural con su Sailing the Wine-Dark Sea: Why the Greeks Matter (Doubleday, 2003). Él explica: 
[...] quiero volver a contar la historia del mundo occidental como la historia de los grandes dadores de dones, aquellos que confiaron a nuestro cuidad uno u otro de los singulares tesoros que constituyen el patrimonio de Occidente.

Dedicado a Desmond Tutu, el libro y la serie en la que fue publicado demuestran cómo se define una cultura en la forma de un enunciado moral y político.

Relacionemos la medida de este horizonte con un ángulo exterior de las vías de riesgos de Libia. La ausencia de una entrada bajo su nombre en algunos diccionarios es una representación por sí misma. Un símbolo distintivo que se puede considerar, Libia ha sido siempre un tema delicado en los estudios grecolatinos, y en la mitología comparada de las culturas mediterráneas. En muchos aspectos, puede conferirse un significado a la presencia o ausencia de Libia de un contexto desde la historia política de los griegos y de la filología latina,

Tabla 3 (Hitos importantes)

1. G. Boissières, Esquisse d'une histoire de la conquête et de l'administration romaines dans le nord de l'Afrique et particulièrement dans la province de Numidie, París, 1878.

2. T. Tissot y S. Reinach, Géographie comparée de la province romaine d'Afrique, 2 vol., París, 1884-1886.

3. R. Cagnat, L'Armée romaine d'Afrique et l'occupation militaire de l'Afrique sous les empereurs, París, 1912.

4. J. Mesnage, L'Afrique chrétienne, 3 vol., París, 1912-1915.

5. G. Sell, Histoire ancienne de l'Afrique du nord, París, 1913-1928.

6. G. Bardy, L'Afrique chrétienne, París, 1930.

7. P. de Labriolle, Histoire de la littérature latine chrétienne, París, 1947.

8. G. Bardy, La Question des langues dans l'Eglise ancienne, París, 1948.

9. F. Chamoux, Cyrène sous la monarchie des Battiades, París, 1953.

10. H. Leclerq, L'Afrique cbrétienne, 2 vol., París, 1954.

11. G-C. Picard, La civilisation de l'Afrique romaine, París, 1959.

12. P. Rommanelli, Storia delle provincie romane dell'Africa, Roma, 1959.

13. M. Leglay, Saturne Africaine, París, 1961-1966.

14. M. Benabou, La Résistance africaine à la romanisation, París, 1976.

15. S. Applebaum, Jews and Greeks in Ancient Cyrene, Leiden, 1979.

16. A. Laronde, Cyrène et la Libye hellénistique, París, 1987.

17. P.M. Fraser y E. Matthews, eds., Lexicon of Greek Personal Names I: The Islands and Cyrenaica, Oxford, 1987.

18. R. Brock y S. Hodkinson, Alternatives to Athens: Varieties of Political Organization and Community in Ancient Greece. Oxford, 2000. 
así como con la del Mediterráneo. La historia política en el sentido de que un modo de lectura y comentario sobre los datos concernientes a Libia o a cualqier otra figura de la misma especie, subraya los principios del discurso, en lo positivo o lo negativo. Eso implica abrir una escena inteligible que dé pie a controversias a propósito de las interacciones entre el horizonte normativo de la práctica interpretativa, y las declaraciones que podrían hacerse de las codificaciones y las inferencias del discurso. Dada la autoridad intelectual de la filología clásica, la historia antigua y la mitología comparada, las investigaciones y publicaciones sobre Libia en los últimos ciento cincuenta años favoreció la confabulación de la historia colonial del siglo XIX y las triunfantes ambiciones positivistas de las disciplinas históricas. Como un efecto de tal configuración, las representaciones de Libia — la ninfa y la tierra-, son intrincadas. Por una buena razón, dado que su función está subordinada a dos argumentos en conflicto: de un lado, la autoridad imperial de una razón colonial; y del otro, el dogmatismo de las presunciones del siglo XIX en lo que respecta a los modelos científicos objetivos. De los dos, uno tenía que estar supeditado; al menos, como cuestión de conveniencia.

¿Queda algo por estudiar en el campo de la África grecorromana?, pregunta E. Mercier en 1895. La pregunta parece sincera. Es ingenua, sin embargo. Hecha en reconocimiento de lo que se ha logrado en el campo durante el siglo. De cualquier modo, implica que se ha hecho todo lo posible, y que se ha hecho bien. De hecho, llama la atención a la investigación de Mercier y al capítulo sobre «La población indígena de África bajo la dominación romana, vándala, bizantina», publicado en el compendio oficial de noticias y memorias de la sociedad arqueológica de Constantino (Recueil des Notices et Mémoires de la société archéologique de Constantine) (30, 1895). El texto de Mercier no se ocupa de los derechos políticos de los «nativos». Medio siglo más tarde, en nombre de las deliberaciones culturales, un descendiente de la población, M. Benabou dialoga en La Résistance Áfricaine à la romanisation (Maspero, 1976). El estudio, rigurosamente inscrito en la tradición intelectual francesa, ejemplifica la misma heurística normativa.

La apreciación de una diferencia difícilmente podría culpar a la aplicación de los métodos históricos y filológicos. Un conocimiento genérico contextual sí lo haría.

Para hablar de las "Lessons" from the Past de E.R. May (Oxford University Press, 1973), tendría que confrontarse un entendimiento entre los requerimientos técnicos y las opciones morales, y por ende políticas. Mercier escribe un artículo académico en el apogeo del periodo glorioso del régimen colonial francés en África del Norte. Entrenado durante la guerra algeriana en la misma tradición, Benabou modifica una percepción a la vez que se mantiene fiel a las prescripciones epistemológicas de una disciplina. 
Acceder a las dos obras al mismo tiempo en busca de una síntesis sobre la aculturación en el África romana del siglo III significaba, para mí, consignar oeuvres públicas en una tradición científica. Eso estaba contemplando una diversidad y relacionándola con otros discursos para Combats pour un Christianisme Africain (Facultad de Teología Católica, Kinshasa, 1980). Las condiciones de posibilidad de las oeuvres en presencia, comprometen contextos del imperio colonial, condicionamientos objetivos y configuraciones epistemológicas. Los hitos de la Tabla 7 muestran intersecciones de voces subjetivas en la ciencia con sus matices poéticos.

«Les oeuvres ne passent point toutefois comme passent les ouvriens» (Las obras no pasan como pasan quienes las crean), dice Maxime Chastaing en L'Existence des autres (Presses Universitaires de France, 1951:312). La evidencia que podría no parecer obvia es un "porqué no», que es una manera de revisitar Libia en la Bibliotheca, con el fin de restituirle de nuevo algunas de sus inscripciones y apropiaciones.

La biblioteca francesa del siglo XIX sobre las colonias griegas y el África romana (-las provincias de Cirenaica, África, Numidia, y las dos Numidias), al traducirse como una biblioteca francesa de los pasados del norte de África, esta simple sustitución en la designación, funde dos incomparables. La tentadora aplicación a los pasados de una red política postcolonial, en particular la alienaciónefecto de la desigualdad en las relaciones sociales de producción en el espacio colonial, puede ser peligrosa. Eleva en bloque complejas cuestiones que deberían distinguirse. Incluyen lo siguiente. Uno, existe el problema de una correlación entre, de un lado, la dominación (económica y política), como práctica cíclica e isócrona; y, del otro, la capacidad normativa, como justificación de la autoridad moral. La reciprocidad es una hipótesis. Dos, está el caso de un sistema de valor externo que explicaría una posible homología entre un tipo de colonización del siglo XIX, y los sistemas coloniales griegos y romanos. Eso es igualmente una hipótesis. Tres, por decir lo menos, de estas hipótesis, ¿no debería enfrentarse lo que se está defendiendo, en términos de los saltos deductivos en relacion con una voluntad de verdad que explicaría sus principios?

La ejemplar reflexión expejo del logro de Benabou frente a la declaración de Mercier ilustra la base para la creencia de que los argumentos bien fundados en la política de la alteridad no son argumentos alternativos en las prácticas disciplinarias. La lista de hitos (tabla 3), de las recientes bibliografías sobre Libia, incluyen buenos testimonios. Son ejemplos inspiradores en la negociación de prácticas disciplinarias «intuitivas» $\mathrm{y}$ «formales», codificaciones téorico-culturales frente a los cimientos normativos y a la idoneidad.

Puede accederse de otro modo a la persistente influencia de la Bibliotheca. Afirma esto la edición de la Loeb Classical Library, establecida por Sir James G. Frazer, el autor de The Golden Bough (MacMillan, 1922), considerada por The Times «uno 
de los libros más influyentes del siglo XX». Al final del segundo volumen de la Bibliotheca de Apolodoro, sir James G. Frazer anexó trece estudios sobre antropología cultural comparada. A las temáticas de la antigua Grecia (como el origen del fuego, la resurrección de Glauco, Edipo, etc.), presenta creencias y costumbres de todo el mundo de nuestros días, desde el Ovambos sudafricano y los antiguos mexicanos, hasta los indígenas de Thompson y los aborígenes australianos, la baja Normandía y el pueblo rumano, etc. y entonces, no es sorpresa que, a manera de regresión, se revisite el análisis estructuralista de los mitos griegos en la Structural Anthropology de Claude Lévi-Strauss, el vademécum de un método probado en el estudio de las culturas no occidentales.

Una relación con su propia historia y la del Mediterráneo, la Bibliotheca es también una relación con sus fábulas. Su memoria se funde con el origen de Mnemosine

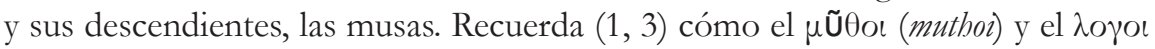
(logoi) se reflejan entre sí en Hesíodo y Homero. En Eikones (3, 1, 25), Filóstrato

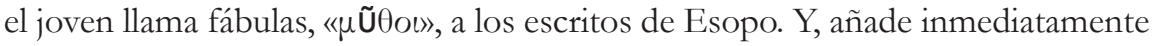
que Homero, Hesíodo y Arquíloco apreciaban el valor de la fábula. A lo largo del Eikones, Homero sirve como autoridad sobre los muthoi. Estos comprenden leyendas, así como observaciones factuales cotidianas sobre arte, el gusto y referencias históricas. Polisémico, muthos significa palabra y dicho, declaración e informe. Su correspondencia con el significado de la historia ficticia e imaginaria es a la vez conceptual y una extensión semántica. Llegó a oponerse a logos, y el último que supone la idea de la verdad histórica.

La manera como Esopo describe las conductas humanas a través de animales expresa un punto moral, indica Filóstrato. Y el artista sabe que al inventar fábulas,

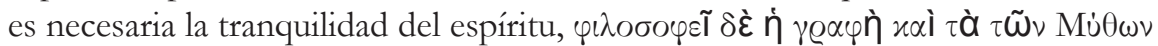
$\sigma \dot{\omega} \mu \alpha \tau \alpha(3,2,10)$. Logos y philosophein no están aquí desligados de los muthoi. Sus significados se cruzan. Traen consigo asociaciones de verbos como, de un lado, mutheomai ( $\mu \cup \theta \dot{\varepsilon} о \mu \alpha \iota$ ), que en el activo significa «consideran»; y en la forma pasiva significa «referirse a algo a la manera de los seres humanos»; mutholegein ( $\mu$ Ũ $\theta 0 \lambda \varepsilon \gamma \varepsilon \iota \nu)$, «narrar una historia de manera fabulosa»; y, del otro lado, muthopoiein

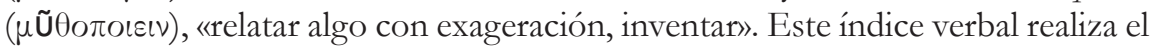
valor de encuadrar y planificar algo, lo cual es frecuente en los textos de Platón y Aristóteles, y está en su mayor parte determinado por la estructura que une


fábula y el acto de construir.

En un aspecto importante, la Bibliotheca de Apolodoro refleja un reconocimiento público en las representaciones griegas. Se ocupa de asuntos del universo y su génesis, el pasado griego y sus lecciones, dando detalles y haciendo comentarios sobre una memoria colectiva. Es griego en su peruigilium, como se señaló antes, un derecho a las interpretaciones establecidas entre sus escritores y exégetas, 
así como una exención de las mismas. En la introducción a la edición que creó para la Biblioteca Clásica Loeb, sir James G. Frazer resume bien la calidad de la Bibliotheca, comparándola con el libro bíblico del Génesis. Anota que, aunque definitivamente acrítica, la Bibliotheca es sin embargo completamente confiable para lo que la explica:

[...] desde las mejores fuentes literarias abiertas a él, la Biblioteca de Apolodoro nos presenta una historia del mundo, como la concibieron los griegos, desde el oscuro principio hasta una época en la que las nieblas de la fábula comenzaron a elevarse y a revelar a los actores reales en la escena. En otras palabras, Apolodoro nos conduce desde las eras puramente míticas, que yacen mucho más allá del alcance de la memoria humana, hasta el límite de la historia (1922:xx).

\section{MESITEIA}

Génesis en el sentido del origen que significa y el registro de tal proceso, la Bibliotheca problematiza la historia y la historia problematiza la Bibliotheca. Su estructuración desembrolla un esfuerzo por dar coherencia a un patrimonio y por inculturar lo extranjero en su topografía. La Bibliotheca ejemplifica una Graeca Interpretatio. De manera análoga a la Interpretatio Romana de Tácito, el concepto designa una actitud y una relación con cualquier alteridad y su transcripción al griego.

«Una razón por la que los historiadores griegos y romanos no llegaron los modernos estándares de la historiografía fue por sus errores. Consignaron varios hechos en forma equivocada», escribe Michael Grant en Greek and Roman Historians: Information and Misinformation (Routledge, 1995:88). A partir de la práctica actual, Grant menciona tipos que deben asociarse con un problema. Los errores de los antiguos que aparecen en su lista incluyen: (1) amor por una historia y sus resultados en una mezcla acrítica de aphesis (relato y bon mot) con la historia (historia); (2) auto-justificación, un énfasis exagerado del interés pro-cúpula en el reporte de eventos; (3) influencias, en el sentido de una excesiva repercusión de las presiones externas; (4) chovinismo, al que se reduce prontamente la criticada noción del etnocentrismo; (5) sobrevaloración de las guerras, en las explicaciones de las relaciones de causalidades; (6) culto a la biografía en las interpretaciones, pues depende de la idea de una predestinación; (7) finalmente, la intención moralizante de cualquier relato histórico.

Dar crédito a dicha lista significa suscribirse a un ideal de la historia. Grant explota consistente terminología de la prescripción de Leopold von Ranke. Al menos, escribe, «para tratar, por consiguiente, de conseguir nuestros hechos como son y en el orden correcto, en el tiempo y el lugar correctos». Específicamente, «es tarea del historiador descubrir las ideas detrás de los hechos. El historiador debe mostrar 
porqué sucedieron las cosas y descubrir las fuerzas que había en juego» (1995:92). En relación con la Bibliotheca de Apolodoro, deben deducirse varias precauciones didácticas de las expectativas de una práctica objetivista de la historia.

Primero que todo, contra la tentación del anacronismo en la evaluación de los historiadores del pasado, estamos de acuerdo con Michael Grant, y reconocemos la capacidad inherente de cualquier trabajo intelectual de trascender las limitaciones que lo definen y de contextualizar su objeto. Son tres, y son ineludibles: la conciencia, el tiempo y el espacio del sujeto. En segundo lugar, existe un condicionamiento interpretativo. Los especialistas, por ejemplo, anuncian la originalidad de Diodoro Sículo, Dionisio de Halicarnaso, Dío Casio y otros «oligarcas», como los llama Grant, desde una doble comparación. Ello implica, por un lado, una referencia a su inscripción en una continuidad; y, por el otro, a una visión convencional de la disciplina.

Aun desde la época de Heródoto y Tucídides, el reflejo ha estado ejerciendo una disociación entre aféresis e historia, convirtiéndolo en un criterio extremo. Este condicionamiento es paradójico. En efecto, el discurso histórico es calificado en forma simultánea de la manera como debería reproducir patrones relevantes que regresan a una génesis, y a partir de su obediencia a una disciplina, asegurando su credibilidad intelectual. De manera coextensiva, los requerimientos poco realistas de tal historia objetivista contribuyeron en nuestro tiempo al surgimiento de la nouvelle histoire, cuyos argumentos han ido socavando la historia positivista. El cambio de alguna manera permite nuevos tipos de compromiso con el estilo de la Bibliotheca y por ende un cuestionamiento sobre lo que es la historia. La introducción de Peter Burke a New Perspectives on History (Pennsylvania State University Press, 1992) ha resumido de manera adecuada las líneas principales de los nuevos enfoques. Basta reconocer aquí que el paradigma de que «todo tiene una historia» es una reivindicación de la Bibliotheca como un tesauro de la historia mediterránea. En breve, el nuevo espíritu puede capturarse a partir de unas pocas proposiciones. Primero, cualquier objeto puede valorarse a través de una multiplicidad de continuidades. Segundo, los vestigios escritos y arqueológicos generan solo una especie posible de registros. Tercero, no hay razón para privilegiar discursos de arriba sobre los de abajo, los cultos sobre los populares; ni para favorecer siempre lo esperado de lo académico sobre los cuentos populares.

La crítica del positivismo, iniciada a comienzos del siglo XX por un Karl Lambrecht en Alemania, se fusionó con tendencias similares en el Reino Unido y en Francia. El nuevo llegó a identificarse con la Ecole des Annales en la década del 30, bajo la guía de Marc Bloch y Lucien Fèbvre. Uno de sus logros más visibles ha sido la obra de Fernand Braudel sobre la cuenca del Mediterráneo. 
La soberanía de la Bibliotheca mantuvo el objetivo de los relatos de Heródoto sobre el conflicto como criterio explicativo en los asuntos humanos y divinos. Inspiró nuestra lectura de la institución de las casas reales y sus efectos. Libia no puede separarse de ello. El primer libro de Heródoto señala este hecho en los dos movimientos, dos argumentos fundacionales en realidad, de su proyecto, para recordar un pasado y honrar las hazañas de los griegos. Un evento inicial, el rapto de Ío, involucra a Libia. Enciende un ciclo de atropellos y sus desgracias, la saga de una historia y de sus ilusiones. La Bibliotheca de Apolodoro narra la cronología de antiguas bibliotecas y su historia que se remontan a Heródoto y más allá de su obra. Pero Heródoto había expuesto los gestamen.

1. La historia de Ío, abuela de Libia

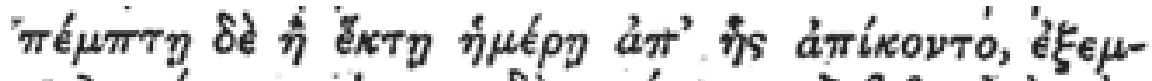

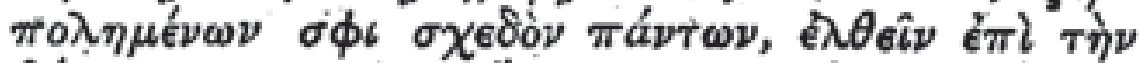



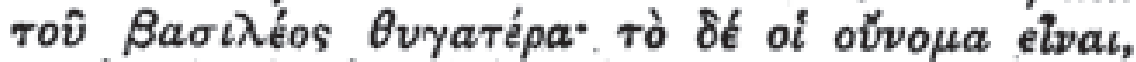

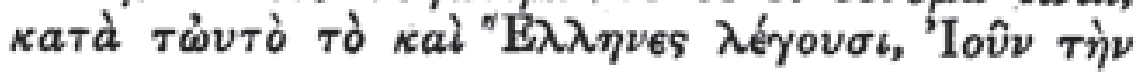

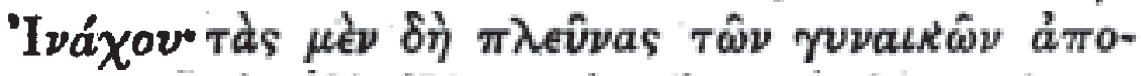




'̇ं ${ }^{\prime}$ 'Aiyúmtov.

«Ío, dicen los persas, y no los griegos, fue raptada; arrojada al barco y llevada en dirección a Egipto [...]». En la Bibliotheca (2, 1,3), la hija de Yaso, Ínaco, o Piren, se ha rendido al amor de Zeus, y es víctima de los celos de Hera. Para protegerla de Hera, es transformada en una vaca. Para escapar de su omnividente Argos, vaga por Micenas, por Europa y Asia hasta Egipto, donde da a luz un hijo de Zeus, un

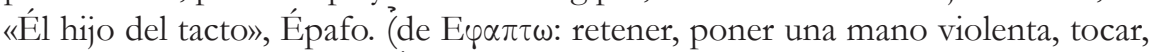
manipular indebidamente). Ío, dice Apolodoro, engendró una hija, Libia, de cuyo nombre proviene la región de Libia $(2,1,4)$. Diodoro Sículo identifica a Ío con la egipcia Isis $(1,24,8)$.

\section{La historia de Europa, nieta de Libia}

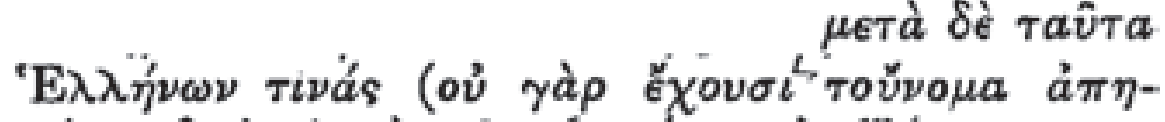

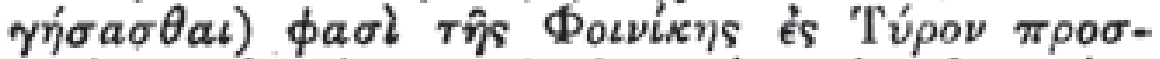

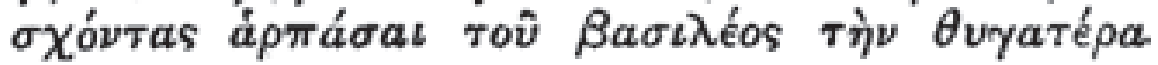

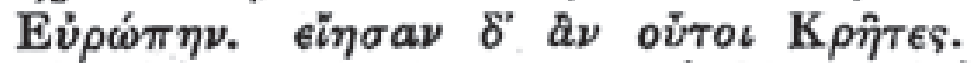


«[...] ciertos griegos (no pueden decir quiénes) desembarcaron en Tiro, en Fenicia, y se llevaron a Europa, la hija del rey. Estos griegos deben, supongo, ser cretenses [...]». Eú@ó $\eta$, hija del fenicio Agenor y de Teléfasa, seducida por Zeus quien se había transformado en un toro blanco. Apolodoro da detallas de la expedición marina desde Asia hasta Creta $(3,1,1)$. De Zeus, ella es madre de Minos, Sarpedón y Radamante. Europa es la esposa de Asterio.

3. La historia de Medea

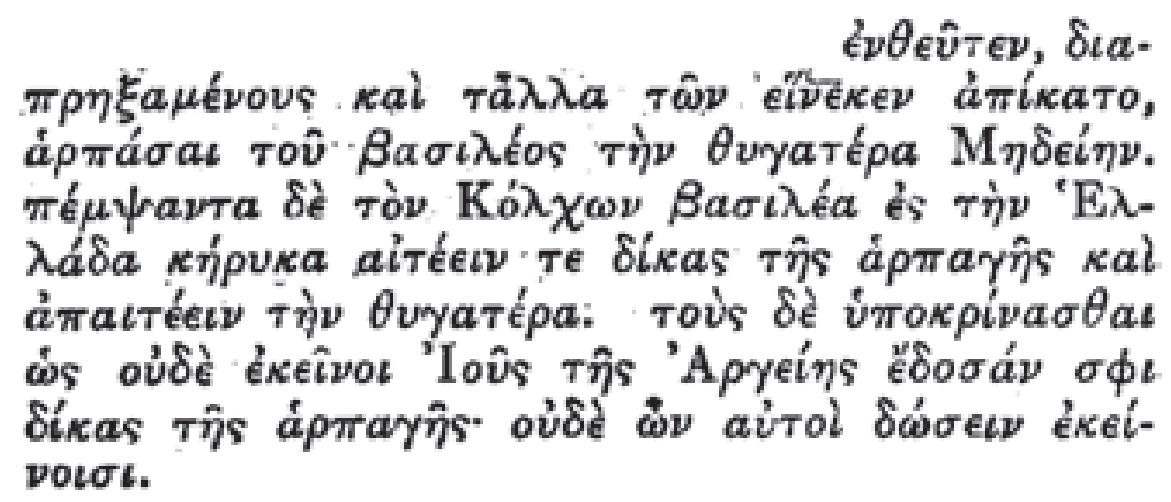

Integrando una referencia a la historia de los argonautas, el texto afirma: «[...] después del asunto para el cual vinieron, se llevaron a Medea, la hija del rey $[\ldots]$ ». A la protesta de los cólquidos, «los griegos replicaron que así como ellos habían rechazado reparar el rapto de la argiva Ío, tampoco ellos harían ninguna a los cólquidos». La Bibliotheca resume la historia oculta de Medea. Su esencia se amplifica en la imaginada confrontación de Eurípides (-te salvé, pues todos los griegos saben quién se embarcó contigo). Los libros 1 y 2 describen a la hija del rey cólquido Acetes, una bruja que seduce a Jasón, asesino y aventurero de recio carácter en Corinto, Atenas. Restaurador del reino de Colquis, Medea ha sido asociada a medesthai, como lo señalaron Price y Kearns en su diccionario (2003:338). Una referencia más sencilla sería $\mu \varepsilon \dot{\delta} \delta \omega$ (reinar sobre, proteger) y $\mu \varepsilon \dot{\delta} \delta \mu \alpha \iota$ (ser conciente de algo, urdir tretas). En el Epitome de Apolodoro (5, 5), Medea se une con Aquiles. James George Frazer sugiere una comparación con $\operatorname{Argon}(4,815)$ sobre esta unión desconocida por Homero.

4. La historia de Helena, media hermana del padre de Libia




«Luego (así sigue la historia), en la segunda generación. Alejandro, hijo de Príamo, habiendo oído esta historia, consideró tomar una esposa para sí mismo de Hélade por rapto [...]. Así que tomó a Helena». Centro de una guerra troyana de diez años de duración, el nacimiento de Helena es una leyenda tal como lo son la mayor parte de los eventos de su vida. La Bibliotheca lo sintetiza en unas cuantas frases como un misterio $(3,10,7)$ :

[...] Zeus en la forma de un cisne se unió con Leda, y la misma noche ( $x \alpha \mathbf{l}$

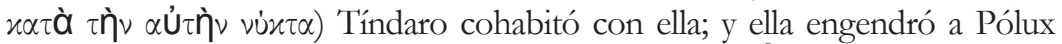


Clitemnestra de Tíndaro. Pero algunos dicen que Helena fue hija de Némesis y de Zeus; porque ella, volado de los brazos de Zeus, se convirtió en gansa ( $\tau$ ǹv

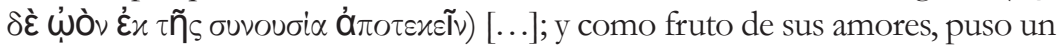
huevo, y cierto pastor lo encontró junto al río y lo llevó y se lo dio a Leda; [...] y cuando Helena se incubó a su debido tiempo, Leda la crió como a su hija.

Para acomodar las versiones de los relatos sobre Helena, la Bibliotheca tipifica representaciones de la esposa de Menelao. De un lado, la chica raptada por Teseo, y rescatada por Cástor y Pólux $(3,10,7)$, se duplica en el Epitome $(1,24)$, en el que Helena tiene doce años y es salvada por los dióscuros con los lacedemonios y los arcadios; la mujer tomada por Alejandro (París), como era la voluntad de

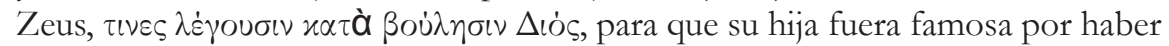
enredado a Europa y Asia $(3,1)$. De otro lado, unoso cuantos párrafos abajo, se hace una diferencia entre la real Helena, que va a Egipto con Hermes en obediencia a la voluntad de Zeus; de aquella que Alejandro se lleva a Troya (3,


fantasma quien desposa Deífobo a la muerte de Alejandro. En efecto, según Heródoto $(2,113)$, «de Esparta, los vientos se habían llevado a Alejandro (París) por el mar, las partes egea y etíope, los llevaron hasta la boca del Nilo».

El Epitome $(6,29)$ da coherencia a los dos rostros de Helena. En su camino a Attica, las naves de Menelao se desvían. Errantes, después de Creta, navegan por Libia, Fenicia, Chipre y Egipto. En la corte de Proteo, rey de Egipto, encuentra a

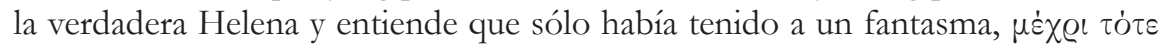

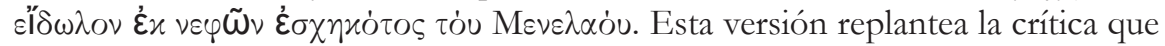
Heródoto hace de Homero por la estancia de Helena en Egipto (2,112-116).

Una maldición en un lado, y en la otra, la migración, que se inscribe en los cuerpos, y tiene la transculturalidad como efecto. Estos tres ejes que animan la «Casa» de Libia, su progenie. Puede decirse que las líneas que ellos generan contrastan mucho de una ley en un discurso que refleja un evento lingüístico. Una figura, el discurso es en sí mismo La voluntad de Zeus, para usar el título de A History of Greece from the Origins of Hellenic Culture to the death of Alexander de Stringfellow Barr (J.P. Lippincott, 1968). 
Tabla 6
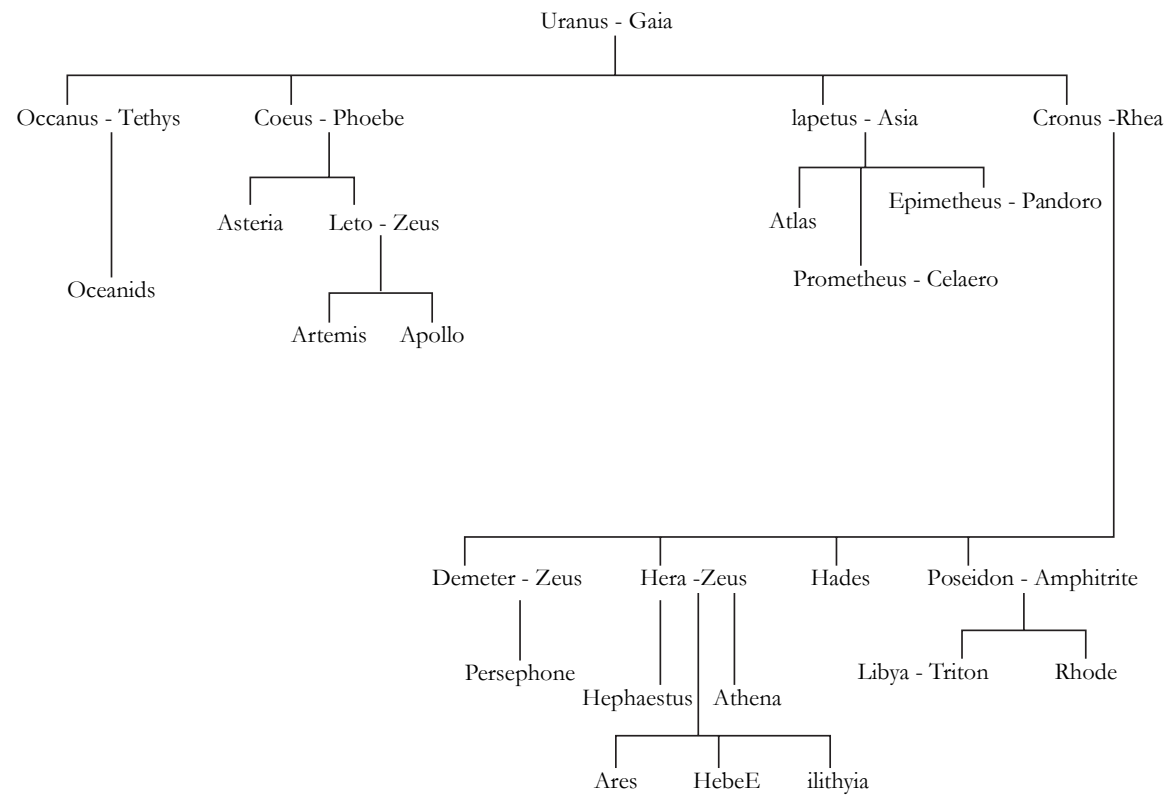

En el trasfondo, una guerra. La pasín de Helena, hija de Zeus, reina de Esparta, transcribe un presente temporal en la memoria de otros testimonios mediterráneos importantes. El rapto de Helena en la lista de la explicación de Heródoto sobre la guerra persa, mucho después de La Iliada, se remonta a anteriores secuestros, así como a su propia textualidad. Todos los autores que comentan sobre ello recurren a la historia de un texto proyectado. Dión Crisóstomo (aprox. 40/50 d. C. - después de 110) defiende la virtud de Helena contra las mentiras de Estesícoro en Peri Basileias (B., 13). The Life of Apollonius of Tyana, de Filóstrato, reactualiza la observación de Heródoto. Pasó a ser una denuncia: «se nos engañó y timó para enviar emisarios a los troyanos y pelear batallas en creencia suya» $(4,16)$. Helena estaba en Egipto, $\dot{\eta} \delta$ 'Ä̈үı $\pi \tau \dot{o} \nu \tau \varepsilon \dot{\omega} x \varepsilon \iota$

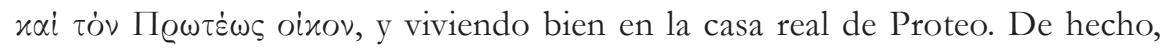
ella personifica una compleja tradición. Celebrada por Eurípides en Helena, junto con Í $o$, igualmente Helena puede ser victimizada, y lo es. La evidente lección helenocéntrica fue bien enunciada en From Solon to Socrates: Greek History and Civilization de Victor Ehrenberg (Methuen, 1968). Las historias son «todas variaciones de la antigua temática del reconocimiento (anagnomisis), y al mismo tiempo dejan la astucia humana o el triunfo de la inocencia no sólo a los enemigos bárbaros sino también a los dioses» (1968:310). El lugar real de las guerras es un cuerpo femenino. 
Posiblemente a finales del siglo II, para el obispo cristiano Aquilles Tacio de Alejandría, Helena es simplemente una mujer entre otras, incluida en una maldición de género:



¡Oh, mujeres, mujeres, que viven en nada! Si aman, matan: y si no aman, matan también.

La preconcepción ya era transparente en el informe de Heródoto (1, 4), simbólico y funcional. Simbólico en la forma como parece asumirse y no excusarse una violencia, y funcional por la manera como representa una razón para algo más. Así, algo, una ofensa, un robo (Helena), habría justificado una invasión. Los griegos, informa Heródoto, invadieron Asia antes de que los persas atacaran Europa. «Pensamos», dicen, «que es malo llevarse las mujeres: pero el celo excesivo en vengar el estupro es insensato: [...] pues claramente las mujeres nunca se hubieran dejado llevar si no lo hubieran deseado». Dos, una pregunta: «[...] Nosotros de Asia en modo alguno consideramos la violación de nuestras mujeres; pero los griegos, todo por consideración a una lacedemonia [...], vinieron a Asia, y destruyeron el poder de Príamo». Tres, una correlación entre la abducción y la retaliación. Heródoto justifica incluso eso, dirigiéndose a un ausente interlocutor asiático:

Desde entonces consideramos nuestros enemigos a los griegos ( $\tau$ ò

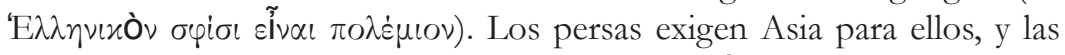


ท̆ $\eta \eta \tau \alpha \iota)$ Europa y la raza griega de la que se mantienen separados $(1,4)$.

La cuestión de las razas o las naciones se traduce también en una cuestión de lo que une a continentes interconectados. En la Bibliotheca, Libia llama a la luz a Hércules, Menelao, Ulises, etc. Las deidades errantes son un símbolo de generaciones de instituciones sociales. Un antes asume los peligros de lo primitivo desconocido, y un después se refiere a una presencia griega. Estas líneas representan espacios que los dioses ponen en regla sobre los tres continentes. En la Bibliotheca, el nacimiento de Libia, al igual que la violencia en su familia, son contemporáneos con las tareas simbólicas de Hércules para limpiar el país que lleva el nombre de Libia. El héroe debía liberar a Libia de sus peligrosos animales $(2,5)$. Las lecturas anteriores han tendido a acentuar lo negativo de este tipo de historias. Ellas han suscitado contralecturas afrocéntricas. Al evaluar el daño, pueden notarse dos posiciones elegantes: una introducción popular al problema por Alain Bourgeois, La Grèce antique devant la négritude (Présence Africaine, 1970); y sobre las tareas inferenciales, Engelbert Mveng, Les Sources 
grecques de l'histoire négro-africaine depuis Homère jusqu'a Strabon (Présence Africaine, 1972). A estas afirmaciones, debe añadirse dos contribuciones sobre el «cuerpo racial» en las civilizaciones grecorromanas; un punto de vista clasicista, Blacks in Antiquity: Ethiopians in the Greco-Roman Experience (Belknap, 1971) de Frank M. Snowden, y un estudio más orientado a las ciencias sociales, Black Spark, White Fire: Did African Explorers Civilize Ancient Europe? (Prima, Random, 1999), de Richard Poe.

La ambigua señal en la Graeca Interpretatio puede resumirse en la exclamación de Juvenal: Tibi habe frumentum, dum tubera mittas $(5,119)$. Señala una metáfora de una lucha permanente en la evaluación de enunciados inferenciales. En la oposición entre frumentum y tuber, lo ambiguo lee lo semántico siguiendo la corriente (con un valor positivo), en relación con el singular primario de tuber, tumor (con su significado negativo de una excrecencia enferma). Una ambigüedad semántica viene a invadir las consideraciones sobre una memoria cultural. Afirma una tradición, una estructura de figuras conflictuales y las formas de interpretarlas. La ambigüedad comprende otras figuras. Son variantes de un prototipo femenino. Como ya se observó, está primero el nombre mismo de Libia. Entre los mitos y la geografía, revive una referencia incrustada en la intersección de una violencia original y de las guerras históricas. Está en segundo lugar la tierra que nombra, y el epónimo afecta todas sus figuras. Trae consigo otra geografía del exceso, una negativa. Heródoto superpuso una geografía de la monstruosidad sobre su geografía de las narrativas del norte de África. Podría no haber verificado todo lo que le dijeron, confiesa. Diodoro lo conservó (3, 50-59) con su obsesión fundamental por los seres femeninos atrapados en la unión de la naturaleza y la cultura.

A propósito de Libia, en los márgenes de esta razón griega, opuesta a una luz interior, y acusado en la misma razón que lo produce, se encuentran signos viciados. Es el caso del símbolo significado en la alegoría del mito libio de Dión Crisóstomo. En el quinto discurso, Dión expone los riesgos de sucumbir a los encantos de lo que alertan una rara especia de sirenas que tienen cabeza y torso de mujer, y la cola de una serpiente. El motivo ya se ha invocado en el cuarto discurso, un peligro libio a la ambición de Alejandro de «prevalecer sobre todas las mujeres y todos los hombres» (4,73-74). Un ikon femenino, peligros y salvaje, este duplica la representaciones del ocasional esposo de Libia, Tritón. Hijo de Poseidón, tiene la parte superior humana y cola de pez. Para J.W. Cohoon, editor de la edición Loeb de Dión Crisóstomo, el símbolo femenino, según una «idea popular era el de un espíritu o genio interno que poseía y controlaba a los hombres» (op. cit. :203 n2). Símbolo para recordar, enseña, dice Dión, que Hércules, al asumir su tare de destruirlo, cumplió una obligación moral de dominar su corazón, y al hacerlo, la obligacion de civilizar la tierra. 


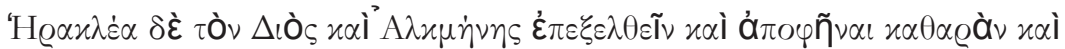


$\dot{\eta} \mu \dot{\varepsilon} \varrho \omega \sigma \nu .(5,23)$

[...] pero ese Hércules, el hijo de Zeus y Alcmene, llevó la tarea a su término e hizo su corazón puro y dócil o manso; y que esto es lo que se dice de su amansamiento, es decir, civilizar la tierra.

\section{KORMOS}

En To Speak is Never Neutral (Routledge, 2002: 193), sobre el asentamiento en el psicoanálisis, Luce Irigaray señala una pregunta importante: «¿Cómo podemos hablar de análisis desde dentro de su entorno? ¿Desde dentro de la escena?» Esto puede tocar a Libia. En efecto, desde el ambiguo enunciado de Juvenal, Libia, un símbolo eponímico, puede decodificarse al menos de dos maneras. De un lado, está Libia la tierra, con sus colonias griegas, provincia romana, y lo que Juvenal sugirió indirectamente atañe a los bienes agrícolas por los que se conocía la tierra, en el tiempo de Juvenal, servía como granero de Roma; del otro lado, está la dimensión simbólica de la ninfa Libia, en la intersección entre lo humano y lo divino.

En la Bibliotheca (2, 1, 3-4), en el cruzamiento de la geografía y la mitología, Libia refleja una cara del mar Mediterráneo y el mar la refleja a ella, en las interpretationes griega y romana. Nacida en Menfis, hija del eponímico Nilo, el río, Libia es esposa de Poseidón, el dios de los terremotos y del mar. En la intersección de los campos simbólico y conceptual de aquello a lo que estas cualidades prestan atención, es una imagen de valores en conflicto: agua y fuego, germinación y destrucción, fecundidad y catástrofe. Los dos hijos de Libia están igualmente asociados con el mar, Agenor en su reinado sobre Fenicia, en el Mediterráneo; y Belus sobre Egipto, de esta manera el Nile y el casamiento con Anquínoe, hija del Nilo. La costa que lleva su nombre identifica una relación con el mar, y precisamente, desde lo que el mar permite al leer a Apolodoro, l'économie antique, en referencia al tratado de J. Toutain sobre este tema específico (La Renaissance du Livre, 1927). Héroes errantes, Menelao, Ulises, Hércules, cualifican una topografía. El último determina sus fronteras al erigir los pilares que separan a Europa de Libia $(2,5,10)$; y al este, distinguiéndola del Egipto gobernado por Busiris. La pacificación de la tierra que Hércules realiza pide también una lógica la explicación de las colonizaciones griegas en Epitome $(7,15)$. Los griegos errantes se establecen alrededor del mar Mediterráneo. En una costa del Mediterráneo, de cara a Libia, una historia económica dominante que, en una minuciosa lectura de los clásicos, Toutain describe desde Homero y las sociedades Hesiódicas hasta el periodo helenístico y romano; y en interacción, e igualmente parte de la misma dinámica, el Cercano Oriente, Cartago, el sur de Italia, la península Ibérica. La 
diversidad económica puede abordarse, demuestra Toutain, desde el concepto


antique» mediterránea. El MIT Journal of Interdisciplinary History, Quid nobis cum pelago, parece basarse en una razón similar.

El mare nostrum de los latinos designa un corpus nostrum, nuestro cuerpo, según el C.G. Jung de Mysterium Coniunctionis (Princeton University Press, 1974: 5).

Disociando las líneas simbólicas a propósito de Libia, es posible hacer énfasis en tres entradas. Divina y humana, ella representa un enunciado peligroso. Primero, es la madre de un juicio permanente en su descendencia, atrapada entre excesos en lo positivo y lo negativo. Segundo, un espacio geográfico, identificado con la costa sur del Mediterráneo, es a la vez un paisaje fecundo al servicio de las culturas mediterráneas, y una representación de fronteras que temer $(2,5,10)$. Finalmente, este mismo valor de miedo ligado a Libia parece más evidente cuando interviene Tritón, el hijo de Poseidón mitad pez mitad humano. Desde el nombre, al menos dos ejes se intersectan en la Bibliotheca. De un lado, la imagen de una Atenas libia nacida alrededor del río Tritón (1, 3, 6), y traída consigo por Tritón $(3,12,3)$.

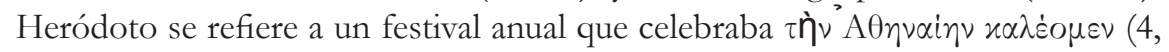
180), a quien los Maclies que vivían alrededor del lago tritonio llaman Atenas. Del otro lado, es alrededor de esta misma área que Heródoto $(4,185-90)$ sitúa una sólida colonia griega, y Diodoro $(3,53,6)$ un dominio gobernado por las amazonas. En todos los casos, el lago tritonio parece una sinécdoque; dando coherencia a lo que amplía y consumiendo lo que puede presuponerlo. Y aquí, se toca un punto importante en las representaciones de Libia.

Diferenciemos tres umbrales.

En primer lugar, en esta tierra que lleva su nombre, desde Heródoto hasta la Bibliotheca, además de comprender un espacio infirmitas, esencialmente más allá del radio de acción griego que es el lago tritonio, Libia contiene una cultura que epitomiza la figura arquetípica de Artemisa. Heródoto describió los Oiorpata, una raza de homicidas $(4,110)$. Los llevó lejos al Oriente desde el mar Mediterráneo, después de haber vencido en el continente y en el territorio escita. En la Geographia, Strabo (64 A. de C. — después de 21 d. C.) detalla otra ginecocracia al norte, aislada en una isla de Aquitania $(4,4)$. Diodoro Sículo retrata la más elaborada organización, una alternativa bien estructurada a la mayoría de las sociedades mediterráneas. En «las partes occidentales de Libia», escribe, «en los límites del oikoumenê, una raza

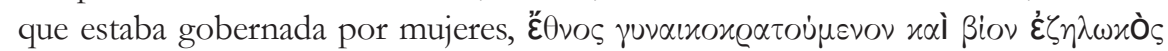

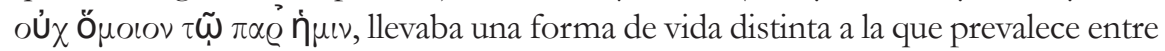
nosotros» $(3,52)$. La Bibliotheca menciona varias veces a las amazonas, incluyendo la novena tarea de Hércules, de traer el cinturón de Hipólito $(2,5,9)$. Su presentación 
de la marcha contra Atenas en el Epitome (1,16-19) duplica la de Diodoro Sículo $(4,28,2)$. La intervención de los escitas recuerda la de Heródoto sobre la no integración de las amazonas al modelo dominante de la Graeca Interpretatio. El encanto de esto ha sido retomado en el lenguaje actual por The Last of the Amazons de Steven Pressfield (Doubleday, 2002).

En segundo lugar, es en Libia, en las partes occidentales, alrededor del lago tritonio, aun cerca de Etiopía según Diodoro Sículo que existen las formaciones thêlukratès mejor estructuradas, o reinados de mujeres. Bajo la guía de Mirina se lanzaron a la conquista del Mediterráneo (3, 53-70). Además en los márgenes de Libia, habita la raza del fenómeno descrito por Dión Casio, mitad humana y mitad serpiente, un punto medio entre la figura de la sirena y el tritón. Según Jung en Mysterium Coniunctionis (op.cit.), el alarmante símbolo de Dión, ambiguo sin duda como cualquier humano, puede simplemente denotar un tipo de conocimiento que no siempre es peligroso. Asociada con Tritón, y atrapada ella misma entre dos especies y dos naturalezas, Libia moderaría visiblemente a los seres atrapados entre un modelo Mediterráneo model y sus posibles negaciones. En esta lectura del mito libio, Dión advierte:

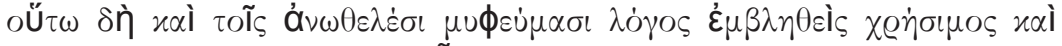

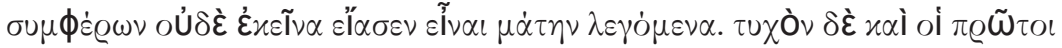

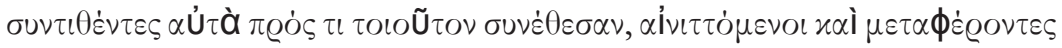

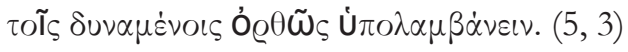

Y del mismo modo, cuando se imprime alguna moraleja útil y edificante en una fútil leyenda, se salva la última de ser una simple historia vacía. Quizá, también, quienes compusieron estas historias en primer lugar lo hicieron para algún propósito similar, usando la alegoría y la metáfora ya que ellas tenían el poder de interpretarlas correctamente.

En tercer lugar, Apolodoro maneja el tópico según la tradición. El hogar es el mejor lugar para normalizar lo inesperado. El Epitome (1, 16-19) sintentiza fielmente la lección sobre la marca contra Atenas y la victoria de Teseo sobre las amazonas, por ejemplo. La muerte de Hipólito habla contra las alternativas. Dión moraliza de manera diferente. Lo que se debe temer combina los contrarios. Transgrede las normas sancionadas por las oposiciones lógicas: la verdad contra la mentira, lo bueno contra lo malo, lo bello negando lo feo. La monstruosidad es aquí el nombre de lo que disputa la racionalidad griega. El peligro libio primitivo de Dión es una metáfora mortal: sirena y tritón, ella es una bella mujer; serpiente y ser humano, tenía alas; del mar y de la tierra, vive en márgenes apartados. Lleva todas las señales de un orden que contradice el sentido común, la razón y la ética normativa. 
Tabla 7a



Finalmente, podría invocarse el desafío del nacimiento de Atenas y el Paladio, un argumento importante en el volumen de Bernal sobre la evidencia lingüística. Ilustra bien nuestro modesto punto de un Mediterráneo intercultural. Uno, las cuestiones del nacimiento de Atenas y el Paladio están en la Bibliotheca relacionadas con Tritón quien, según Apolodoro, tuvo una hija Palas. Sir James G. Frazer señala, "Apolodoro como de costumbre se limita a la tradición griega» (1922, vol 2: 41). En la tradición, hijo de Poseidón y Anfítrite, el dios marino Tritón. 
Tabla 7b

\begin{tabular}{|c|c|c|c|}
\hline $\begin{array}{l}\text { UILERAIVH } \\
\text { DC }\end{array}$ & $1560-1060$ & $1000-500$ & 5000 \\
\hline countay & \multirow[b]{2}{*}{ 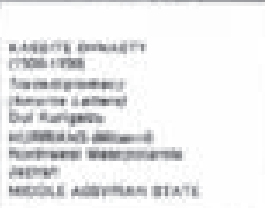 } & \multirow{2}{*}{  } & \multirow{2}{*}{ 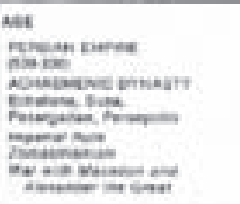 } \\
\hline $\begin{array}{l}\text { MESOpotania } \\
\text { Mid IRAS }\end{array}$ & & & \\
\hline \multirow[t]{2}{*}{ Earet } & \multirow[t]{2}{*}{ 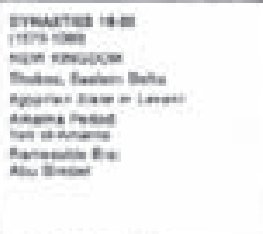 } & \multirow[t]{2}{*}{ 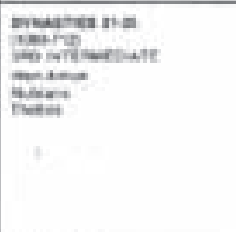 } & 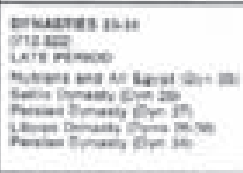 \\
\hline & & & couico mowas \\
\hline \multirow[t]{2}{*}{$\begin{array}{l}\text { 5raia } \\
\text { PALESTIE }\end{array}$} & \multirow{2}{*}{ 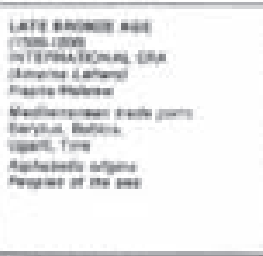 } & 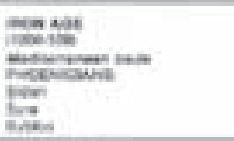 & \multirow[t]{2}{*}{ naween sus } \\
\hline & &  & \\
\hline AMATOLLA &  & 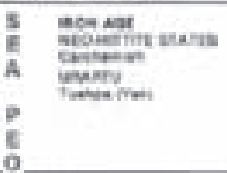 & pramay tast \\
\hline \multirow{3}{*}{$\begin{array}{l}\text { AEOENi } \\
\text { ANO } \\
\text { CrPAus }\end{array}$} & 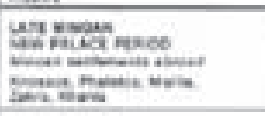 & \multirow[t]{3}{*}{$\frac{1}{6}$} & \\
\hline & 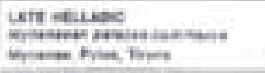 & & \\
\hline & 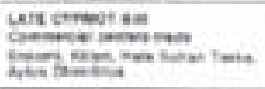 & & \\
\hline
\end{tabular}

está ligado al área del lago tritonio, y al río Tritón. Heródoto lo presenta como perteneciente a esa región de Libia $(4,178-9)$. Diodoro Sículo sitúa las amazonas en la misma área (3, 52-59). Según Apolodoro, «Atenas, completamente armada saltó de la parte superior de la cabeza [de Zeus] al río Tritón» (1, 3, 6). Apolonio Rodio la llama la Atenas tritonia $(1,105-9)$. En cuanto al Paladio, Apolodoro lo relaciona con ejercicios de guerra de las dos niñas, Atenas y Palas, que vivían con Tritón (3, 12, 3). Dos, Heródoto trata de manera crítica ambas ideas. Diferencia una diosa libia de Atenas, y afirma que «los griegos recibieron su escudo y su yelmo de Egipto» $(4,180)$. En cuanto a Tritón, la confusión, según A.D. Godley, editor de la edición Loeb de Heródoto (vol. 2), «puede surgir del hallazgo que hicieron los argonautas [en Libia] de un río que les recordaba a su río Tritón en Boecia» (4, 180, nota). Parsanias ( 9 , $33,7)$ y Strabo $(9,2,18)$ confirman tal designación, según el Lexicon de Liddel Scott. 
En resumen, en la Bibliotheca, lo mítico y lo histórico, lo culto y lo popular, están en concordancia. Describen las historias en conflicto de una unidad transcultural profundamente estructurada y sin embargo de cierta forma invisible. Sería una memoria subterránea que los retratos contrapuestos han estado una vez más tratando de atestiguar. De un lado, más conforme con una perspectiva clásica, Mediterranean Portrait of A Sea de Ernle Bradford (Harcourt, 1971) y, radicalmente innovadora, la obra de Fernand Braudel, notablemente Les mémoires de la Méditerranée prébistoire (Éditions de Fallois, 1998). Del otro lado, ha habido recientes desafíos de intervenciones africanas en egiptología, un Cheik Anta Diop con Civilization or Barbarism: An Authentic Anthropology (Lawrence Hill, 1991), y Théophile Obenga con La Philosophie Áfricaine de la période pharaonique 2780-339 avant nôtre ère (L'Harmattan, 1990). Entre las dos tendencias, los volúmenes de Martin Bernal sobre Black Athena: The Afroasiatic Roots of Classical Civilization, en estos pasos: (1) The Fabrication of Ancient Greece 1785-1985 (1987); (2) The Archaeological and Documentary Evidence (1991); (3) The Linguistic Evidence (2006).

De la Bibliotheca:

El cielo fue el primero que reinó sobre el mundo entero. Y habiendo desposado a la Tierra (Гñ), engendró primero los de las Cien manos $[\ldots]$

Después de ellos, la Tierra (Гñ) dio a luz a los Cíclopes [...]

Y nuevamente engendró hijos con la Tierra, es decir, los Titanes como se les llama $[\ldots]$

Pero de nuevo $[\ldots]$ desposó a su hermana Rea $[\ldots]$

Hera, y después de ellos Plutón y Poseidón. Furiosa por esto, Rhea reparó a Creta $[\ldots](1,1-7)$.

Este es el comienzo de la creación que, en su edición de la Bibliotheca de Apolodoro, Sir James G. Frazer llama con buena razón, una génesis. Recupera el génesis bíblico. Ambos textos, la Biblia y la Bibliotheca, se han calificado como «ficción». $\mathrm{Y}$ potentemente, si se entiende la ficción como la designación de cualquier narrativa o historia que, como las matemáticas abstractas o la lógica formal, la ciencia ficción o la teología, no se ajusta a la evidencia factual. De otro lado, ambos pueden leerse desde su contexto histórico. The Bible as History de Werner Keller (Hodder y Stoughton, 1956) cuestionó esta noción de ficción llamando la atención a rasgos que podrían calificar de otra manera las historias bíblicas. Eligió hacer énfasis en el «incesante tráfico de mercancías de todo tipo que despachaban las grandes firmas de importación y exportación de Mesopotamia y Egipto por rutas de caravanas o por mar desde el golfo Pérsico hasta Siria y Asia Menor, desde el Nilo hasta Chipre y Creta e incluso hasta el Mar Negro, se refleja en 
su correspondencia comercial, que realizaban en tabletas de arcilla o papiro» (1956:28). El punto no es demostrar en detalle la veracidad de las narrativas, sino la coherencia de una información que confirma el hecho de un intenso comercio. La Bibliotheca repite otras génesis pasadas del Mediterráneo.

Sobre todas estas narrativas, míticas e históricas, el problema real ha sido de cronología. Debe abordarse aquí reconociendo los efectos de los problemas fundamentales planteados por Peter James en Centuries of Darkness: A Challenge to the Conventional Chronology of Old World Archaeology (Rutgers University Press, 1993). La Bibliotheca se lee como una versión de antiguas bibliotecas. Se refieren a pasados complejos. La datación rigurosa de sus eventos y ciclos despejaría formas hipotéticas de distribución de mapas culturales. Una simple norma de prudencia obliga a percatarse de la advertencia de Colin Renfrew, el profesor de arqueología de Cambridge, que introduce Centuries of Darkness:

Este perturbador libro llama la atención de manera penetrante y original, sobre un crucial periodo de la historia universal, y sobre la naturaleza supremamente inestable de la datación, el completo marco cronológico, sobre el que reposan nuestras actuales interpretaciones. Ese periodo es, en términos muy simples, el tiempo de surgimiento del mundo antiguo —es decir, el mundo clásico de Grecia y Roma antiguas- que siguió al declive de las grandes civilizaciones de la Edad de Bronce en el Mediterráneo y al inicio del «Oscurantismo». Esas civilizaciones — los hititas, los micenos, Egipto en el Nuevo Reino- decayeron o colapsaron. Y después de algunos siglos emergieron los nuevos mundos de la antigua Grecia, de Roma, de los etruscos y así sucesivamente. La revolucionaria sugerencia Se hace la revolucionaria sugerencia [en el libro de Peter James] de que las cronologías existentes para esa crucial fase de la historia humano están erradas por varios siglos, y que, en consecuencia, la historia tendría que reescribirse (1993:XIII).

Y las líneas finales del mismo Peter James exigen al menos dos cosas: impulsar en principio las nuevas hipótesis plausibles; y, por la fuerza de las circunstancias; de otro lado, usar aún las dataciones disponibles para lo que siempre han sido, aproximaciones en las historias de las hojas de ruta mediterráneas y su relación con las civilizaciones a las que servían.

Todas estas pueden verse ahora como producto de una causa común —una fe mal puesta en la inmutabilidad del marco establecido. El Oscurantismo resultante y todas sus ramificaciones en realidad equivalen a un disparate académico monumental, perpetuado por la conveniencia de una escala temporal aparentemente confiable, así como a la total complejidad de los problemas involucrados. Nuestra investigación muestra que estas 
controversias han sido en gran medida innecesarias. Con la cronología menor que aquí se propone, muchas simplemente desaparecen, junto con las ilusorias Centurias de Oscuridad (1993:320).

Relacionada con las interacciones culturales, la Bibliotheca da fe de lecciones a las que un Paul Veyne ha dedicado dos interrogantes cruciales: Writing History (Wesleyan University Press, 1984); y Did the Greeks Believe in their Myths? (The University of Chicago Press, 1988). Esencialmente, él está de acuerdo con las posiciones de Michael Grant que, hablando sobre la incompetencia de los historiadores griegos y romanos, insiste en que «hay ciertas razones para estar pesimistas». Pero lo mismo debería aplicarse a nuestra época: «ipodemos confiar en que alguien nos diga, de manera confiable, lo que está pasando?» (1995:126). $\mathrm{Al}$ menos existen buenas razones para analizar la modernidad de los historiadores griegos y romanos en nuestra reconstrucción de su pasado. Los textos griegos interpretan líneas de intersección a través de movimientos transculturales activos de ideas, personas y hojas de ruta que corroboran comunicaciones e intercambios transnacionales, y viceversa.

Existe una interdependencia entre la circulación de mercancías y personas y la constitución de colonias. Colonia puede significar una comunidad establecida de inmigrantes que viven en un país que no es el de origen, ni el de sus ancestros. 'Aлоюжо es el término griego para colono. Designa a alguien que vive lejos de casa, como cuando Heródoto llama colonos a los milesios porque sus ancestros

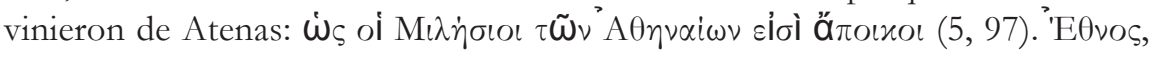
frecuente en el lenguaje de Heródoto, Diodoro y la Bibliotheca, tiende a aplicarse a importantes comunidades y puede significar de manera indistinta nación, personas o grupo. De hecho, la palabra usada se aplica también a los animales. Ese no es el caso de su cuasi sinónimo demos ( $\delta \tilde{n} \mu \circ \varsigma)$, usado generalmente para las personas que habitan en la misma área; de ahí, el significado de población, una colonia, un país. En Indo-Europaan Language and Society (University of Miami Press, 1973), Émile Benveniste hace una buena indicación al señalar que $\delta \tilde{n} \mu o \varsigma$ designa a grupos «unidos únicamente por su categoría social y no por algún vínculo de parentesco o adhesión a una comunidad política» (1973:372). El último valor es lo que corresponde a ' $₹ \tau \theta$ vos para grupo de inmigrantes. Los colonos pueden incluso estar bien integrados en las estructuras de la región, como los fenicios y los cartagineses y sus descendientes han vivido en la península Ibérica durante siglos. Se consideraría, por ejemplo, la palabra para las comunidades griegas de Cartago, Siracusa, Menfis, Sidón o Tiro en el siglo V a. C. De este modo, una colonia no implica permanencia, tampoco necesariamente posesión en la tierra. En este sentido, colonia puede designar un asentamiento o a sus miembros. 
TABULA RASA

No.11, julio-diciembre de 2009

Tabla 9a

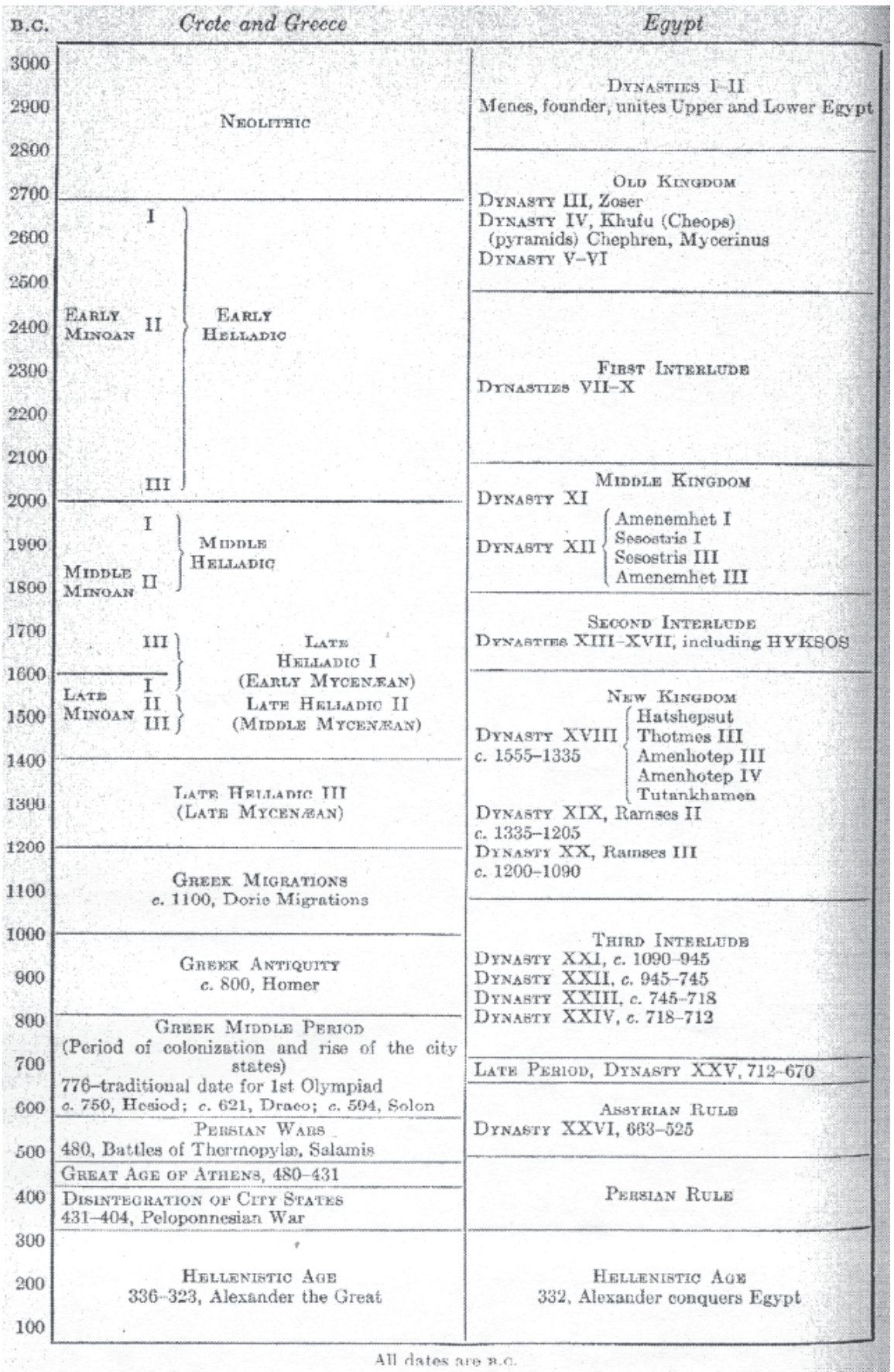

Tabula Rasa. Bogotá - Colombia, No.11: 141-193, julio-diciembre 2009

ISSN 1794-2489 
VALENTin Y. Mudimbe

En la casa de Libia: Una meditación

Tabla 9b

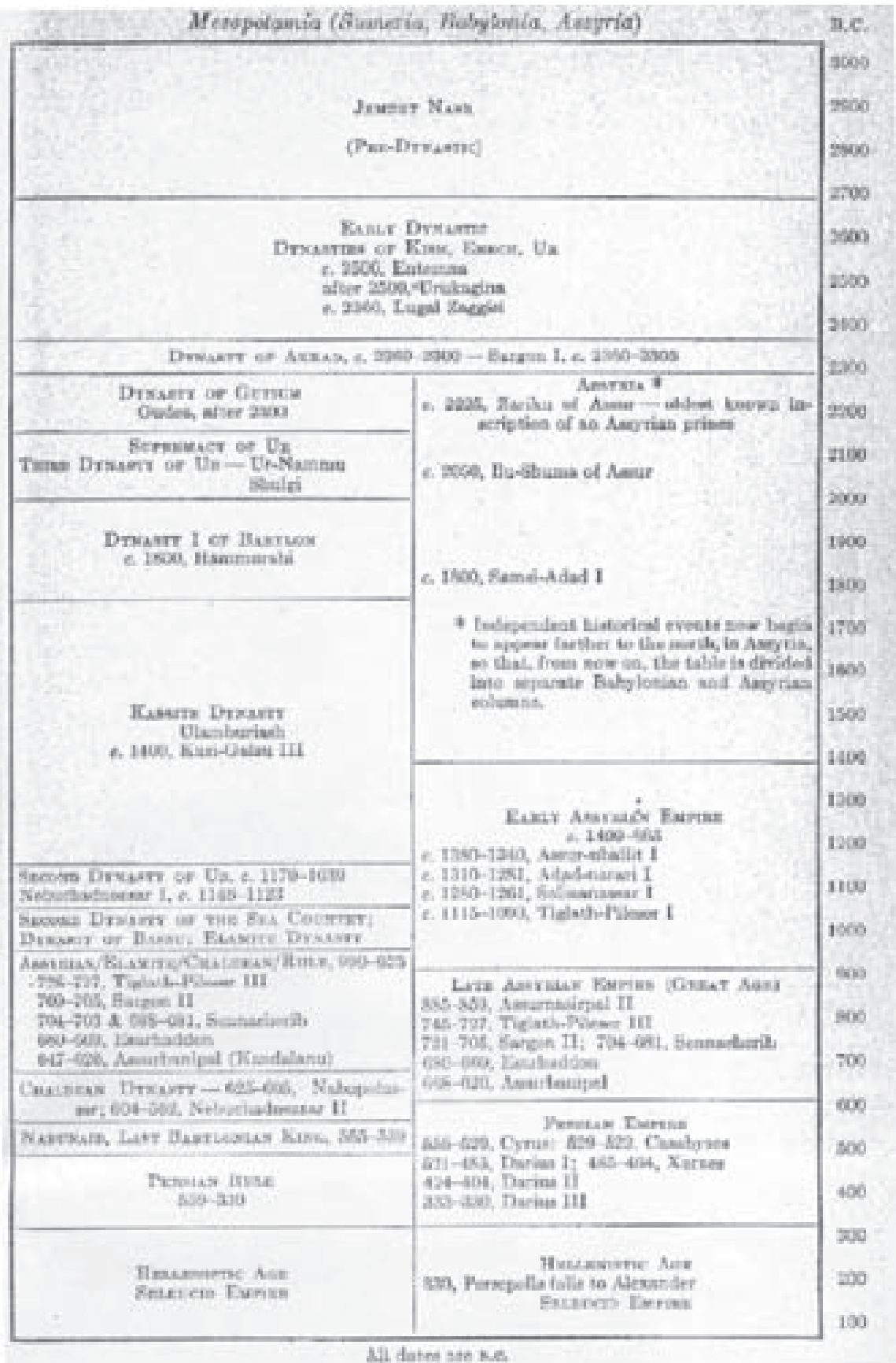

Tabula Rasa. Bogotá - Colombia, No.11: 141-193, julio-diciembre 2009

ISSN 1794-2489

172 
Hay un enfoque romano cómico a la idea de colonia en De Lingua Latina de Varro $(5,143)$. La institución de colonias se describe desde características definidas: «erant circumducta aratro ab orbe et urvo urb $<\mathrm{e}>\mathrm{s}$; et ideo coloniae nostrae omnes in litteris antiques scribuntur urbes». Tiene un mérito, el de hacer énfasis en la idea de la estabilidad espacioal por un grupo humano más o menos homogéneo. Se encuentra bien especificado este significado en el Lexicon de Freund del siglo XIX:

colonia dicta est a colendo: est autem pars civium aut sociorum, missa ubi rempublicam habeant ex consensu suae civitatis aut publico ejus populi unde profecti sunt consilio, Hae autem coloniae sunt, quae ex consensu publico, non ex secessione sunt conditae, Serv. ad Verg. A. 1.

El recientemente publicado volumen de Greek and Roman Colonization (The Classical Press of Wales, 2006), editado por Guy Bradley y John-Paul Wilson, revisite el uso de la noción de colonia en doble sentido, una crítica a «la influencia de la antigua historiografía», y la confiabilidad de la evidencia arqueológica. Ligada a los estudios postcoloniales contemporáneos, la problematización acentúa dos entradas complementaris al tratar la diversidad de las antiguas colonias, desde todo el sistema de las prácticas griegas y romanas, y desde la singularidad de sus partes. Sin duda, las perspectivas de hoy en día, que reevalúan las colonizaciones grecorromanas, con sus presupuestos éticos sobre los rasgos alienantes inherentes a cualquier colonización, tienen que confrontar el desafío, de hecho la inevitabilidad de la «explicación», un «modelo de leyes cobertoras», para referirse a Laws and Explanation in History de William Dray (Oxford, 1957). En la práctica de los estudios postcoloniales, y a fortiori en lo que ellos podrían atacar, o por la validez ética de una «explicación por la razón», no se puede eludir el llamado a la austeridad de la intervención de Carl G. Hempel en "reasons and covering laws", una reflexión a propósito de la hipótesis de Dray, un capítulo en The Philosophy of History (Oxford, 1974), editado por Patrick Gardiner:

Adoptar la concepción general [...] de la explanación por razones de ningún modo niega que, como Dray lo subraya correctamente, el historiador aduciendo razones motivadoras en la explicación de una acción normalmente busque mostrar que la acción 'tiene sentido' al considerarse a la luz de los propósitos y las creencias que presumiblemente la impulsaron; tampoco busca negar que percibir que una acción como esta tiene sentido pueda ser fuente de gran satisfacción intelectual. Lo que he tratado de defender es más bien que —aparte de la condición problemática del concepto requerido de la idoneidad —la presentación de 
una acción como apropiada a una situación dada, como dotada de sentido, no puede, por razones puramente lógicas, servir para explicar porqué de hecho se tomo la acción (1974:105).

Es posible problematizar las narrativas míticas invocando la historia. Un análisis comparativo de los mapas, a través de sucesivas tablas sincrónicas de la cuenca del Mediterráneo, permite una percepción más o menos aproximada de la capacidad de Graeca interpretatio en su dinámica colonial y transcultural entre el 2500 a. C. y el 200 d. C. de nuestra era. Como ya se señaló, los estándares de las fechas no son un problema que deba abordarse aquí. Las fechas han sido extraídas de fuentes cualificadas. No pretenden poner a prueba una teoría, sino acompañar una interpretación distante de cuestiones de validez epistémica. En otras palabras, a diferencia de las prescripciones teóricas que rigen los argumentos de Martin Bernal para Black. Athena y sus inferencias, esta lectura, una meditación, considera el método normativo y los principios de Bernal una alternativa acertada, pero elige una estrategia más intuitiva y rentable. En lugar de las técnicas inferenciales formales, la opción aprovecha enunciados que pueden deducirse de lecciones inferenciales de las tradiciones así como de hipótesis inferenciales dirigidas a la verificación, como la de Cheik Anta Diop y la de Martin Bernal. El eje cronológico comprende ad montem, la época de las bibliotecas y las pirámides de Egipto, el imperio semita en Mesopotamia, los asentamientos organizados en Creta. Ad vallem, Marco Aurelio es emperador, a la altura del Neoplatonismo y la Helenización de la cuenca y el Oriente Próximo.

La Graeca interpretatio, y la Interpretatio Romana, en acuerdo dentro de la autoridad de la Bibliotheca, explican y coinciden con la historicidad de una obediencia particular a las historias mediterráneas. Un comentario culturalmente autorreferencia de Diodoro de Sicilia al comienzo de la Biblioteca histórica $(1,24,5)$ ilustra una manera precaria de estructuración del conocimiento. «El relato de los egipcios coincide igualmente con la tradición transmitida por los griegos dese muy antiguo». Unilateral, como el método de Heródoto que lo inspiró, y la Bibliotheca que imita la tradición, la historia del mundo de Diodoro instruye a la humanidad dentro de Grecia.

\section{4. $M A P A S^{5}$}

${ }^{5}$ Todos los mapas se han reproducido de Colin McEvedy, The New Penguin Atlas of the Ancient World, Penguin, 2002. Los números de las páginas se citan después de cada imagen.

Tabula Rasa. Bogotá - Colombia, No.11: 141-193, julio-diciembre 2009

ISSN 1794-2489 
TABULA RASA

No.11, julio-diciembre de 2009



(2002:23)

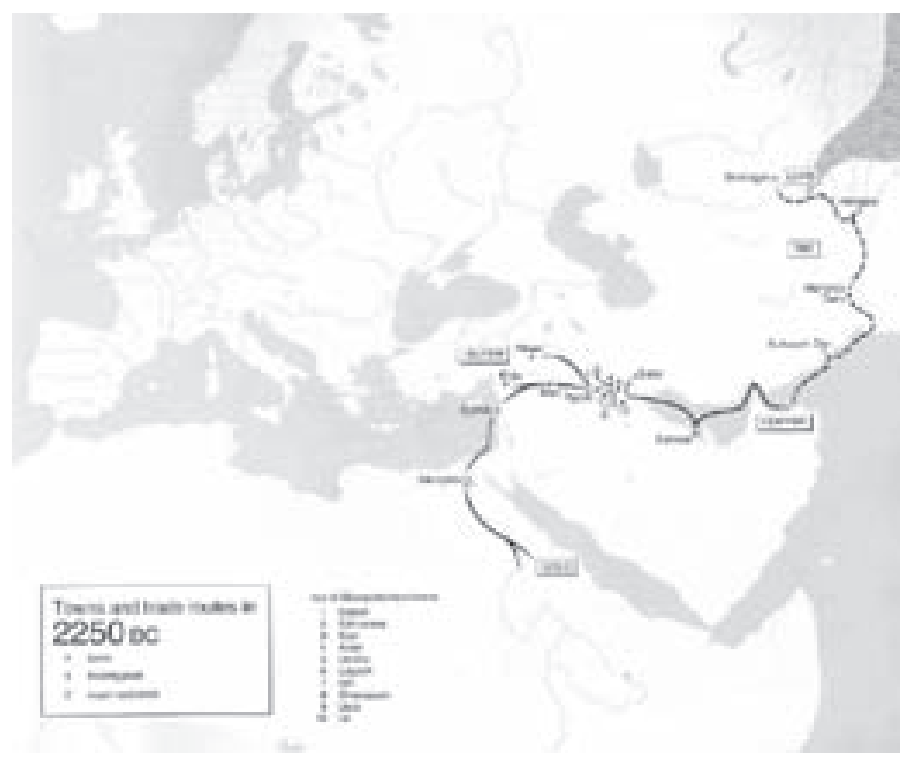

(2002:35) 
VALEntin Y. Mudimbe

En la casa de Libia: Una meditación



(2002:57)

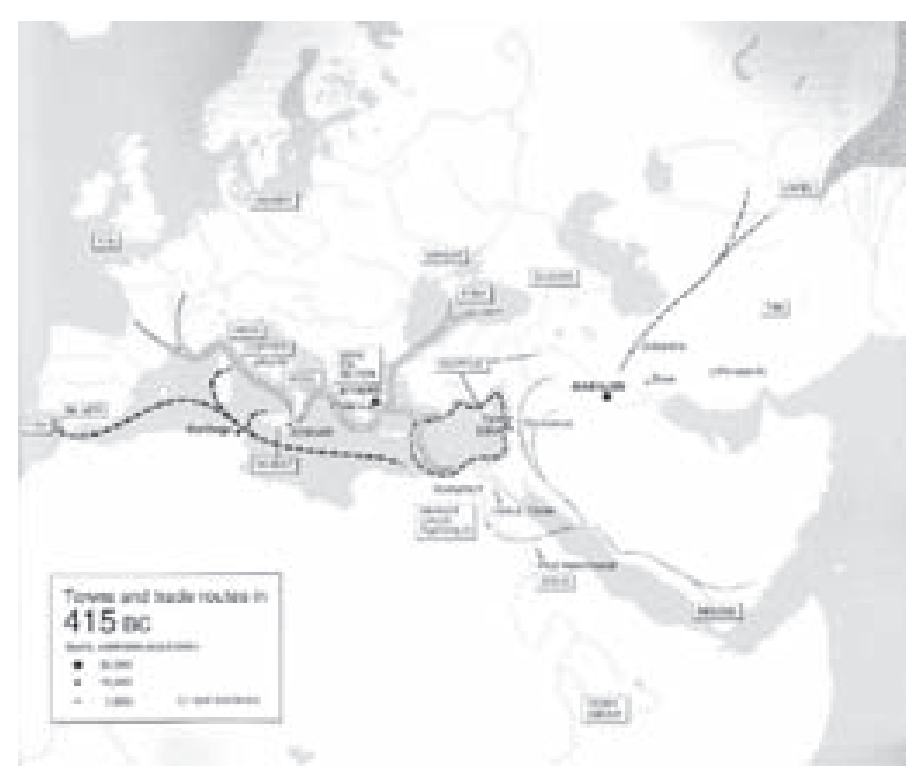

(2002:71) 


\section{ANANKE}

A modo de acentuar la noción de los encuentros, permítanme presentar las principales fuentes secundarias para los griegos, unas cuantas referencias auxiliares, y luego insistir en unas cuantas precauciones metodológicas.

Además de los textos originales editados en la Biblioteca Loeb, debe mencionarse algunas importantes colecciones clásicas. Las más usadas incluyen, Doxographi Graeci de H. Diels (1929), Fragmenta Historicorum Graecorum de K. Müller (18411869), el que aún sorprende por alertar sobre problemas poco comunes, Thesaurus Graecae Linguae (1954) de H. Estienne; la igualmente excelente Scriptores Poeticae Historiae Graeci de A. Westermann (1843). Y la siempre gratificante consulta de A. Forcellini, Totius Latinitatis Lexicon (1940); y la Reäl Encyclopädie der Klassichen Altertumswissenschaft de Paulys-Wissoua-Kroll (1837). Consultadas también habitualmente están las siguientes fuentes: Colin McEvedy, The New Penguin Atlas of Ancient History (Penguin, 2002), la edición revisada de Geoffrey Barraclough del The Times Atlas of World History (Hammond, 1984), $\mathrm{y}$ The Timetables of History de Bernard Grun, una nueva edición actualizada basada en Kulturfahrplan de Werner Steins (Simon \& Schuster, 1979).

A propósito de mapas y transculturas, en términos de método, parece imperativo reconocer los límites de una heurística intuitiva como la nuestra, así cmo las de sus suposiciones epistémicas, dando coherencia a tareas inferenciales, en al menos algunas precauciones a propósito de características muy claras y objetivas, económicas por ejemplo. En primer lugar, un planteamiento crítico de la discordancia entre la cronología tradicional y las temporizaciones de Martin Bernal, acentuando las semejanzas en correlaciones aproximadas, como una prueba contra algunas hipótesis existentes. En segundo lugar, tal evaluación debe tener en cuenta la validez en la proximidad de la tabla 9 en relación con la precaución anterior. En efecto, esta tabla representa una red cronológica cuestionada en Centuries of Darkness de Peter James. Esta red tiene la categoría de conocimiento común. Codificada en Götter, Gräber und Gelehrte de C.W. Ceram (Rowohlt Verlag Gmblt, Hamburg-Stuttgart, 1949), es una reproducción exacta de una tabla que puede hallarse en la traducción al ingles del libro de Ceram, Gods, Graves and Scholars (Alfred A. Knopf, 1951). Es un brillante libro de un arqueólogo lego, ahora un verdadero xoเvós á $\gamma \alpha \theta$ óv, es decir, un bien público común, el canon estándar de una cronología basada en la arqueología, y aun así, publicada el 12 de noviembre de 1951, hacia finales de febrero de 1952, el libro ya tenía seis reimpresiones. Sin duda, parte de un conocimiento colectivo, debe compararse la economía de su cronología con la de un modelo rival, la tabla 7 de The History and Culture of Ancient Western Asia and Egypt (Wadsworth, 1988) d A. Bernard Knapp, del departamento de antropología en la Universidad de Sydney. 
La tercera precaución consiste en el cuestionamiento a la pertinencia de esta muy intuitiva estrategia. Su atención a los dos anteriores puede configurar una lectura sintomática de las interacciones culturales, esa sería una cosa; otra, sería someterla a requerimientos inferenciales normativos en términos de descripción de hechos, explanación y comprobaciones de teorías.

La Bibliotheca de Apolodoro refleja y desvía líneas de narrativas que la explican. Sus interacciones con la historia de Heródoto, o con la Bibliothekê Historikê de Diodoro Sículo, constituyen una gramática del cómo, en obediencia a la Graeca interpretatio, afirman una otredad que les atañe.

«Había una vez...», escribe Jean-Pierre Vernant, fue el título en el que pensó para su The Universe, Gods and Men (Harper-Colllins, 2001). Él cree, en la forma griega y en el sentido griego, en el mito y la mitología, «las leyendas helénicas deben compararse con las historias tradicionales de otros pueblos de muy diversas culturas y periodos, sean en la antigua China, en India, en el Medio Oriente, en la América precolombina, o en África» (2001:ix). No obstante, pura ficción, añade, el mito se distingue de la historia, «diseñada como los recuentos precisos de eventos suficientemente recientes para ser confirmados por testigos fidedignos». La diferenciación permite una oposición entre mitógrafos e historiadores, entre Apolonio de Rodas (nacido aprox. 485 a. C.) y Tucídides (aprox. 460), que se trasciende en dos formas al menos. De un lado, los poetas (Homero) y los autores de tragedias (Esquilo, Eurípides, Sófocles) son fuentes para los historiadores; y, del otro, los historiadores y filósofos contribuyen a los mitos históricos.

Este es el origen de la idea de una génesis. En medio de la Bibliotheca de Apolodoro o la Argonantica de Apolonio de Rodas. Sus historias son la materia prima de los mapas mediterráneos surgidos en la circulación de dioses y humanos, textos y comercio.

«Ahora los egipcios tienen un relato así: cuando en el comienzo surgió el universo $[\ldots] »$, y Diodoro sigue con la génesis egipcia en el primer libro $(1,10)$. Así en el comienzo, dos dioses eternos, la luna y el sol, Isis y Osiris. Diodoro está traduciendo un código, como lo dice a propósito del nombre de otros dioses después de aludir a que Homero habría hecho algo así:

Y además de estos existen otros dioses, dicen, que fueron terrestres, habiendo sido alguna vez mortales, pero que, en razón de su sagacidad y de los buenos servicios que prestaron a todos los hombres, alcanzaron la inmortalidad, siendo algunos de ellos incluso reyes de Egipto. Sus nombres, al traducirse, en algunos casos son los mismos de los dioses celestiales, mientras que otros tienen una denominación distinta $(1,10)$. 
Varias referencias se someten a esta Graeca interpretatio. Dioniso corresponde a Osiris, a la estrella Sirio; Isis, a Démeter; y, de manera notable, Zeus traduce el concepto de la fuente de la vida $(1,12,2)$ :

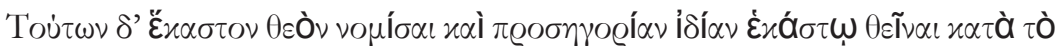

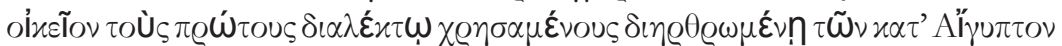



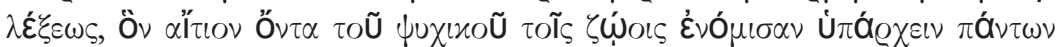

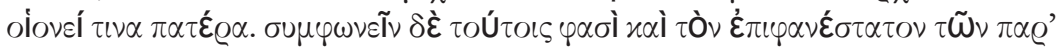



A cada una de estas partes las consideran un dios y a cada uno de ellos los primeros hombres de Egipto que usaron la expresión hablada les dieron un nombre distinto apropiado a su naturaleza. Ahora el espíritu que nombraron, cuando traducimos su expresión, Zeus, y dado quefue la fuente del espíritu de la vida en los animales ellos lo consideraron en un sentido padre de todas las cosas. y dicen que el más renombrado de los poetas griegos también está de acuerdo con esto cuando habla de este dios como el padre de los hombres y de los dioses.

La Bibliotheca traduce también, pero en cierto modo. Eso es manifiesto. Por ejemplo, «Démeter, a quien los egipcios llamaron Isis, e Ío son llamadas de igual manera por el nombre de Isis» $(2,1,3)$. También da cuenta del nacimiento de Zeus en Creta y de genealogías de las divinidades coinciden en una geografía mítica del Mediterráneo (1, 1, 5-6):

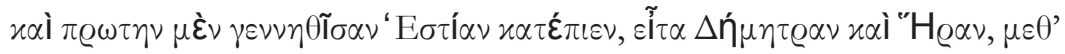

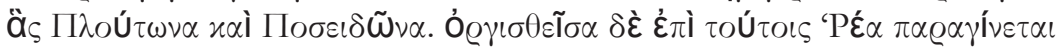

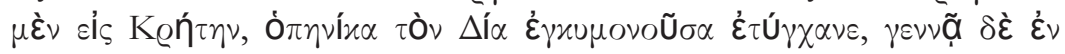

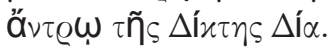

A su primogénita Hestia engulló, luego a Démeter y a Hera, y después de ellas a Plutón y a Poseidón. Enfurecida por esto, Rea se dirigió a Creta, cuando estaba a punto de dar a luz a Zeus, y lo alumbró en una cueva del monte Dicte. Lo confió a los Curetes y a las ninfas Adrastia y Ida, hijas de Meliseo, para que lo amamantaran.

De hecho, la universalidad mediterránea de Zeus está bien afirmada. La Argonautica es ejemplar en este punto.

Para el matrimonio de las hijas de Egiptus y Dánao, la lista de nombres femeninos incluye ninfas y humanas. Las madres de las hijas de Dánao vienen de todo el mar y entre ellas está la esposa etíope de Dánao $(2,1,5)$. Perseo fue a Etiopía, y por el amor de Andrómeda, hija de Cefeo, después de haber asesinado a la Gorgona, enfrentó un monstruo marino y regresó a Argos (2, 4, 2-3). 
Del Epitome de Apolodoro 7, 1:

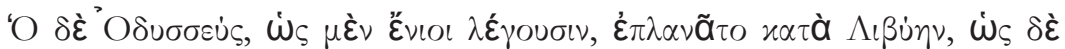

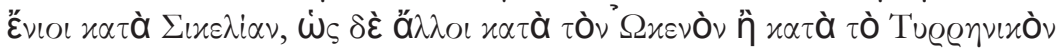
$\pi \hat{\varepsilon} \lambda \alpha \gamma \circ \varsigma^{\circ}$

Ulises, como lo dicen algunos, vagó por Libia, o, como algunos dice, por Sicilia, o, como otros dice, por el océano o por el mar Tirreno.

Y de la Argonantica de Apolonio de Rodas 4, 1773-81:



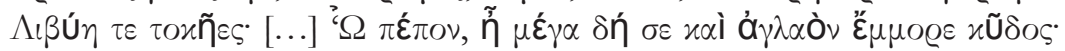

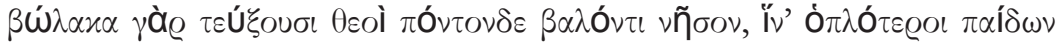

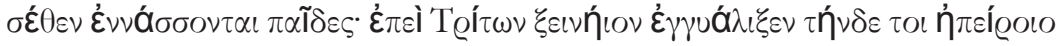

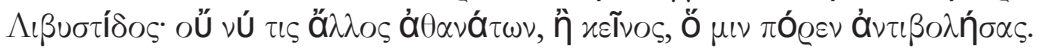

Hija de Tritón soy, estimado amigo, y nodriza de tus hijos, no doncella; Tritón y Libia son mis padres. [...] una profecía de Hécate y elevó la voz y dijo: «Amigo mío, grande y glorioso renombre ha caído sobre vuestra suerte. Pues de este terrón de tierra cuando lo hayáis fundido en el mar, los dioses harán una isla, donde los hijos de vuestros hijos morarán; pues Tritón les dio esto a ellos como presente a un extranjero de la tierra de Libia. Ningún otro de los inmortales aparte de él dio esto cuando os conoció».

Aquí hay líneas que se entrecruzan. El cuadro de un Menelao errante expone una geografía. Menelao, desde el corazón de Ática alcanza Creta, luego es conducido a Libia, Fenicia, Chipre, Egipto. En la corte de Proteo, conoce a la verdadera Helena. De viaje durante ocho años, se detiene en Micenas. Y Ulises asume el mismo espacio: Libia, Sicilia y el Mar Tirreno; y, mirando al sur, llega de nuevo a la costa sur del mar en la tierra de los lotófagos, y así sucesivamente. En el mismo relato, la narrativa homérica coincide con la pena de Medea, se centra en Creta, el reconocimiento de la Atenas minoica y el vínculo de los héroes con el mar de los héroes.

Tres entradas se imponen al organizar el mapa del mar: Creta, Micenas, Libia. Tres avenidas en las que las aventuras de dioses y héroes trazan caminos que los historiadors comentan. Puede reformularse desde la ida de Egeo a Creta y su encuentro con Ariadna, hija de Minos. Los periodos tradicionales son (a) el minoico, 2900 - 1150 a. C.; (b) el miceno (con el saqueo de Troya como acontecimiento central), 1600 - 1150 a. C.; (c) el oscurantismo alrededor de 1200 y la ruina de los complejos micenos en Grecia, 1100 - 750 a. C., con el periodo de Homero y Hesíodo entre 725 - 700 a. C. En la red de Bernal, (a) la temprana Era de Bronce, 3300 - 2000 a. C.; (b) el Periodo Palacial Antiguo en Creta y el Imperio Medio Egipcio, 2100 - 1730; (c) egipcio, levantino, el egeo, 1550 - 1250 a. C. 
Tres ejes de los textos son explícitos. Primero, las aventuras de los dioses y los héroes hablan de un conocimiento geográfico. Explican viajes e intercambios, principalmente de productos agrícolas, hierro y oro. Segundo, las historias tratan de la navegación costera de exploradores Hércules y Menelao. La Bibliotheca, más integral que la Argonautica, refleja a Heródoto. Tercero, los relatos comentan sobre los movimientos de divinidades y poblaciones. Se deben principalmente a las invasiones y las guerras, pero también a las oportunidades de adquirir tierras. Si es difícil diferenciar entre lo humano y lo divino, los dos órdenes interactúan.

En cualquier caso, los modernos observan que entre aproximadamente 2500 a. C. y 1275 a. C., hubo una afluencia de arios, amorreos (son semitas como los mesopotamos invadidos). Les sigue Hyksos alrededor del 1700 a. C. Los conquistadores se someten a las culturas recién descubiertas. Al Oriente, Creta está entrando al periodo superior de la cultura minoica. La erupción de la isla Santorini (Thera) permitió formas de evaluar los niveles arqueológicos sincrónicos del Mediterráneo.

Más que cualquier otra cosa, las rutas comerciales han estado determinando una coherencia geográfica garantizando durante siglos la circulación de personas y mercancías. Desde Menfis en Egipto, hacia Occidente, ejes cruzados conectan a Buto, Knossos en Creta, a Micenas; y hacia el Este, a través de Palestina hasta Alasiya (Chipre), y el puerto marino de Ugarit. Los mapas comerciales asirios trazan la misma área, hacia el norte hasta Sinope en el mar Negro; hacia Occidente, desde Hattusa, o desde Kanesh, hasta Troya en el mar Egeo. Desde importantes ciudades, Elam, Babilonia, etc., y puestos comerciales alrededor del golfo Pérsico y el golfo de Omán, las arterias conectan a Persia y la meseta iraní con el mar Negro.

¿Por qué los minoicos, que no eran griegos, debían escribir en un idioma que no era el suyo? Vieja pregunta de especialistas. En su History of Ancient Western Asia and Egypt, A. Bernard Knapp hace una pregunta similar sobre Siria-Palestina, Anatolia, y el Egeo, sobre las fuentes Hurranias sources y los paralelos griegos. ¿Cómo explicar las detalladas semejanzas estructurales entre la épica Kumarbi y la Theogony de Hesíodo? En el tercer volumen de Black. Athena, Martin Bernal plantea la misma pregunta sobre la importancia de los términos egipcios en griego e insiste en los conglomerados semánticos egipto-semitas. En un enfoque comparativo, reconoció una mayor pertinencia de los rasgos morfológicos (en particular cuando se confirman como excepciones estructurales en cada sistema lingüístico) sobre los cognados léxicos, en aspectos técnicos relacionados con la etimología, las interpretaciones divergentes entre Bernal, y las obras Indo-European Language and Society de Émile Benveniste (1973) y Dictionnaire étymologique de la langue grecque de Pierre Chantraine (Klincksieck, 2000), confirman la «evidencia de contactos e intercambios sustanciales entre Egipto, el Levante y Creta durante el Tercero y el Segundo Milenios a.C.», para citar a Bernal (2006, vol 3:122). Ellos provocan disputas en lo que se refiere a las inferencias cronológicas. 
Lo que hayan adquirido los griegos de los extranjeros, al final lo han convertido en algo más puro, dice el Platón de Epinomis (981d). Está, primero, la geografía documentada de las actividades del Egeo entre 3000 y 1500 a. C., cuyas fronteras conectan la costa oeste de Anatolia con el monte Olimpo al norte, y extendiéndose al oeste, incluye a Leucas e Ítaca, y va hacia el sur a Creta, a la que rodea, y continúa hasta Rodas y Litos, y finalmente, llega a la región sur de Anatolia. Las costumbres del Peloponeso y Creta, con sus rasgos distintivos, el fundamento de un legado.

Martin Bernal se refiere a Apolodoro $(3,14,7)$ sobre la fundación de los misterios de Eleusis, y conectándolo con el periodo de Erecteo alrededor del 1409/8 a.C., hace énfasis en una identificación entre Démeter e Isis, Dioniso y Osiris. El pasaje invocado $(3,14,7)$ es confuso. Apolodoro, en efeco, relaciona el caso del rey Pandión en «cuyo tiempo Démeter y Dioniso vinieron a Ática». Sir James G. Frazer observa que Pausanias $(1,5,3)$ distingue dos reyes con el mismo nombre, algo que también se afirma en Apolodoro (3, 15, 5).

Hay, segundo, los mapas sucesivos de Asia occidental y Egipto. Desde los tiempos prehistóricos, se han estado superponiendo uno sobre otro. Sus esbozos, hasta el periodo helenístico, han estado, de manera permanente y marcada, determinados por una línea que enlaza a Nubia en el sur con Habuba y Halaf en el Arco Fértil. Algunos de sus indicadores incluyeron casi con certeza a Axum y Meroe, al sur de Napata; Elefantina, Abidos y Gizeh a lo largo del río Nilo; Jericó, Biblos y Ugarit en Siria-Palestina, y los montes Taurus en la parte sur de la meseta Anatolia.

El periodo del rey Gilgamesh de Uruk fue también de logros de las Dinastías del Antiguo Imperio (de tercero al sexto) en Egipto, el imperio Acadio y las importantes culturas de Asiria y Mesopotamia. Además de la escritura (jeroglíficos egipcios, glifos proto sumerios y cuneiformes, proto elamita y elamita lineal, y los glifos del valle del Indo), en la ciencia y la tecnología, se reconoce el sistema numérico de Sumer, las observaciones astronómicas en Babilonia, y en India. En Egipto, las ciencias conforman la Pirámide de Keops y el calendario de 365 días. El tráfico económico contribuye a la unión de la cuenca con el mar Rojo. La fundación de Tiro y Sidón por los fenicios, junto con la importación de oro de los egipcios desde Nubia en el este de África; y en Asia, las técnicas de fundición y obras en plata, cobre y lapislázuli, determina ambas geografías de intercambios y políticas de invasiones y guerras.

Los fenicios han ido suplantando progresivamente a los egipcios en la superioridad marítima. Su continuo flujo de intercambios con el delta del Nilo hace parte de un comercio que incluye a Palestina y Filistia. Las rutas marítimas conectan a Tiro y Sidón con Ugarit y más al norte con Cilicia, y al oeste con el Egeo, la costa mediterránea norafricana. 
En otras palabras, alrededor de 1275, existen intensos circuitos entre el imperio egipcio (dinastía 19), la isla de Knossos, y Grecia, Micenas y Tebas. Hacia el Oriente Cercano, los reinos de Asiria, Babilonia y, al sur del monte Nebo, los Israelitas. Desde las tierras altas etíopes, los reinos de Axum y Meroë, la ruta del oro y el marfil va hacia el norte para la época de la dinastía 20, alrededor del 1180 a. C. Hacia el oeste, no hay una frontera real entre Egipto y Libia. Pese a la variedad de sus naciones culturales, el Oriente Cercano constituye un bloque de conjuntos en intercomunicación. Algunas de las rutas más populares se conocen por un nombre étnico calificativo: ruta de los arameos y los caldeos, los cimerios, los medos y los frigios, etc. Facilitadas por los caminos, las migraciones no pueden separarse de una variedad de factores, incluyendo guerras e invasiones más o menos permanentes, expansiones territoriales y catástrofes económicas. De importantes movimientos, deberían señalarse el continuo avance de los fenicios en el Mediterráneo occidental, la ocupación del Peloponeso por parte de los dorios y, como efecto, la migración de los jonios al Asia Menor. Otros importantes movimientos de población tienen que ver con la salida de los israelitas del delta del Nilo, y la expansión egipcia a Asia.

Entre el mito y la historia, la versión que hace Apolodoro de la saga de los argonautas con Medea es un buen punto. Duplica fielmente la Argonautica de Apolonio de Rodas hasta el momento en que Aletes comienza a perseguir la nave $(1,9,23)$. La divergencia es de interés, en cuanto permite una comparación de dos líneas geográficas intercomunicadas. De la Bibliotheca (1, 9, 24-25), interponiendo las referencias de sir James G. Frazer a la Argonautica, se tiene las naciones de Erídano, Ausonia, Liguria y celta, el mar de Cerdeña, la Etruria, Eea y la ceremonia de purificación (Argonautica, 4, 659-717 describe el ritual que incluye un lechón), Caribdis y Escila y el Estrecho de Cinadea (las islas Eolias y sus volcanes), la isla Trinacia, las islas Córcira de los Feacios (variación sobre el rey del sol, Argon 4, 964-979). Luego se mencionan las montañas de Ceronia, Iliria, colonia de Apsirtides, asentamiento de cólquidos entre los feacios, la isla que llaman Anafe (anaphanenai, verse en la lejanía) y un sacrificio (incluyendo una costumbre libia, chanza de mujeres ante el sacrificio, también en Diodoro: 4, 56, 6), Creta y el retorno. En cualquier caso, la Argonautica confirma la universalidad de Zeus; y a él pertenecen por igual suplicantes y foráneos $(2,1131-33)$.

El eólido Frixo había consagrado un altar a Zeus, $\Delta \mathbf{i} \alpha \Phi \cup \xi \xi i ́ \omega$, auxiliador del fugitivo $(4,119)$. Después de una angustiosa noche de lluvia en un barco cólquido, los hijos de Frixo se salvan de la tempestad y oran a Zeus, «dios de los extranjeros y suplicantes». Como si fuera imperativo, hablando de Argos el orante, el autor,

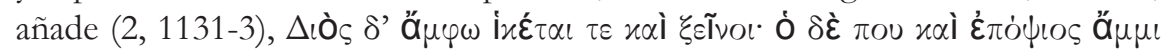
$\tau \dot{\varepsilon} \tau u x \tau \alpha l$ (a Zeus pertenecen suplicantes y extranjeros; y su ojo, a mi parecer, nos mira incluso a nosotros). Aún más ecuménico es el siguiente pasaje que trae 
temáticas de todo el mar Mediterráneo (2, 500-27). Una historia de Cirene, Apolo llevando una mujer de Haemonia a Libia, Febo y su hijo Aristeo, Sirio sobre las islas minoicas, Ceos y los parrasianos, y llega a los sacrificios hechos a «esa estrella Sirio, y a Zeus hijo de Cronos», la mitología asume una geografía y viceversa. Y Zeus es en cualquier caso calificado como el Señor de la hospitalidad $(2,378)$.

Entre aproximadamente el 980 y el 360 a. C., la cuenca mediterránea exhibe patrones de una notable coherencia interna. Por el lado de la integración, los signos incluirían al menos los siguientes. Posiblemente en el 800 a. C., los fenicios mediante el comercio han estado reuniendo pueblos y culturas. Su ruta tiria rodea en círculo los imperios y reinos del cercano Oriente (asirio, frigio, escita, etc.), se vuelve al sur, después de ir hacia el este, llega al mar arábigo y se vuelve marítimo. Sube, por el mar Rojo, luego a través del Mediterráneo y llega al Atlántico. Alrededor del 775 a. C., sugiere McEvedy, sería también la última fecha probable para la fundación de Cartago, tradicionalmente dado como 814.

En Grecia, el conflicto entre Esparta y Tebas, la Guerra del Peloponeso representan uno de los mejores ejemplos de la violencia original entre muthos y logos que Bibliotheca de Apolodoro recita en tareas de conflictos que consolida un mundo de fronteras que se entrecruzan. Un importante fenómeno unificador los sella en lo que Karl Jaspers llamó una era axial, entre los siglos $\mathrm{V}$ y I, la expansión de las religiones universales. La diáspora judía amplía la geografía física del judaismo. Más adelante, la cristiandad y el islam se extienden sigueinte casi las mismas rutas.

En resumen, desde más o menos el 1300 a. C., Grecia se pone en la interconexión de Eurasia y Euráfrica. Tres mapas aprehenden el persistente imaginario de la Bibliotheca.

Finalmente, hacia el 1000, el comercio del hierro había estado uniendo el Mediterráneo con África occidental, desde Cartago y Útica hasta el área de Djenné. Un eje cuasiparalelo también conectaba la misma área con las montañas Atlas y con el puerto de Mogador. Transversalmente, desde el 3000 a. C., otra ruta comercial ha estado uniendo las regiones de Nubia a los mismos confines costeros mediterráneos, atravesando todo el desierto del Sahara por el camino de los macizos del Hoggar y del Tibesti.

Hay una forma de llevar ahora algunas de las implicaciones de una visión afroasiática sobre las culturas del Mediterráneo en su relación con las representaciones de Libia, la madre de Egiptus. De hecho, ellas solo pueden deconstruir la Graeca interpretatio del oikoumene. Se concedería que el adjetivo «afro asiático» usado por Martin Bernal, en una primera aproximación, simplemente significa una forma de privilegiar una entraga a la historia del Mediterráneo. Y, por la idea de génesis afirmada con la noción de las raíces, en el sentido de surgimiento de algo, lo que lleva apela también a la autoridad de la Graeca interpretatio de cara a sus otros, su auto-aprehensión y su crítica externa. En suma, el trabajo inferencial de 
las hipótesis en los pasados real e imaginario de las bibliotecas interculturales y los datos empíricos que han estado acumulando. El énfasis en esta lectura ha sido la visibilidad de la Bibliotheca griega. Sin duda, tal autoridad se confirma a sí misma. Sus órdenes podrían también convertirse en los de otros, correspondiendo literalmente al significado latino de la palabra: el otro de una pluralidad, uno de muchos.

Las diferencias clasifican y, por sus procedimientos, se transforman en conjeturas, es decir, enunciados sobre cómo habitan ellos su propio origen. Sus presuposiciones pueden formularse paso a paso en su razón y su necesidad, la de un binarismo fundamental, y en la tensión de la necesidad frente a la contingencia.

«Ni siquiera un Dios puede hacer frente a la necesidad», dice Platón en Las leyes (741a, 818b). El junguiano James Hillman introdujo una contribución sobre Ananke y Athena en Facing the Gods (Spring Publications Inc., 1980), con esta referencia a Platón, como una forma de entender el término «patologizar» con la importancia de una necesidad, en las trayectorias individual y colectiva. El punto Lo que debe señalarse, observa, es que «la patologización» es el procedimiento fundamental de cualquier narrativa; a fortiori, podría pensarse, cuando supone el muthos y el logos, en la medida en que su ejercicio asigna a sí mismo una vida cotidiana, del presente al pasado. La economía humana de la Bibliotheca refleja el (des-)orden del universo de los dioses:

Las figuras del mito-querellas, engaños, obsesión sexual, venganza, vulnerabilidad, asesinado, destrozos- muestra que los dioses no son solo perfecciones, de modo que todas las anormalidades pueden caer únicamente sobre los humanos. Los mitemas en los aparecen que los Dioses están repletos de comportamientos que, desde el punto de vista secular, deben clasificarse bajo la patología criminal, la monstruosidad moral, o los trastornos de personalidad.

Cuando pensamos mitológicamente sobre la patologización, podríamos decir, como lo han hecho algunos, que el «mundo de los Dioses» es antropomórfico, una proyección imitativa nuestra, incluyendo nuestras patologías. Pero podría empezarse también desde el otro extremo, el mundis imaginalis de los arquetipos (o Dioses), y decir que nuestro «mundo secular» es al mismo tiempo mítico, una proyección imitativa del suyo, incluyendo sus patologías. Lo que los Dioses muestran en un reino imaginal del mito se refleja en nuestra imaginación como fantasía. Nuestras fantasías reflejan las suyas, nuestro comportamiento es sólo mimético del suyo (1980:3).

Madre Libia y la primera generación de su casa confirman esta procesión. En realidad, el argumento junguiano estipula una hipótesis de amplia repercusión. Nuestras posiciones éticas —empíricas y científicas, míticas y spirituales — en la 
lectura de las historias del génesis, significarían una necesidd en el sentido de una «obligación a» forzosa. La afirmación está soportada por textos fundacionales de la filosofía griega (por ejemplo, la Metaphysica, Poetica de Aristóteles; el Cratylus, Leges, la República de Platón), justificada en la razón de Tucídides, invocada por Plutarco en sus Vidas, etc. La Bibliotheca también lo ilustra. En la misma génesis de la historiografía griega, la obligación de Heródoto es un deber. Escribir una


para que la memoria del pasado no pueda borrarse de entre los humanos por la acción del tiempo $[\ldots] »$.

La práctica, una obligación llama la Necesidad, Anankê. Es reclamada con el fin de explicar una sucesión de conflictos entre vecinos dentro del mismo oikoumenê, comenzando con «el rapto de la argiva Ío», hija de Ínaco, aliado de Zeus, y abuela de Libia. Libia llegó a identificarse con una tradición de miedo; y, de una generación a la siguiente, de rapto y violencia. Después de Ío, Europa, Medea y Helena son causas de force majeure para conflictos armados. Implican a comunidades de la misma descendencia: Egipto, Asia, Europa; en suma, tres articulaciones en el mismo bloc, dependiendo de los ángulos, Afro asiático o Eurasiático, el Mediterráneo. La idea de la génesis, en nuestra lectura, se refiere únicamente a la autoridad de la Graeca interpretatio. Para calificar estas formaciones sociales, desde la Bibliotheca de Heródoto hasta la de Apolodoro, la palabra que se usa es ethnos ( $\dot{\varepsilon} \theta \vee \circ \varsigma$ ), que en la traducción se representa de manera indiferente como «nación» o «raza». «Familia» puede equivaler también. Ello contribuye a la percepción de una identidad cultural entendida como la continuidad de la historia de una nación o de una familia, que es el resultado de lo que se ha experimentado y lo que ha atestiguado la Bibliotheca.

El griego 'Av’่ $\gamma x \eta$ equivale simultáneamente al latín necessitas (por necesidad) y necessitudo (obligación forzosa por un lazo de sangre). Presenta tres valores simbólicos principales:

s. en el dominio natural, un eje dominado por, de un lado, la idea de fuerza, que confina pero no obliga; y, del otro lado, la idea de la diferencia, entre cosas o seres, como una calificación de lo que no es idéntico.

t. en el campo especializado de la filosofía y la lógica, un eje bien confirmado en el Metaphysica de Aristóteles (e.g. 1026 28) que define lo necesario, sobre las preposiciones, como designación de lo que se afirma y no puede ser de otro modo; y sobre los seres, como lo que no puede ser de otro modo; mientras que lo contingente sí podría.

u. en el vasto dominio de lo psico-social, dos ejes: uno transmite la idea del destino y la exigencia, igualmente configurado en equivalentes léxicos de idiomas vecinos (como el árabe, hanaka «constreñir»; el hebreo anak «collar», 
símbolo de la dependencia, la domesticidad y la esclavitud); y, un segundo eje, que limita dos valores constitutivos principales —el de la compulsión, y la coacción; junto con el de una intensa presión ejercida por una autoridad, y que implica una obligación moral vinculante.

Para referirse a la Bibliotheca (3, 4, 2-3), allí está el simbolismo del collar que Cadmo le da a su esposa Harmonía. Después de ocho años de servidumbre, el héroe se ha redimido por matar al dragón. Con todos los dioses a su alrededor, le da el collar a Harmonía, un presente de Hefesto, o de Europa, quien lo había recibido de Zeus.

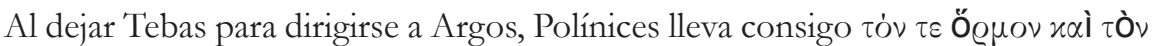
$\pi \dot{\varepsilon} \pi \lambda$ ov $\tilde{\varepsilon}_{\chi \omega \nu}(3,6,1)$, el collar y el vestido que Cadmo diera a Harmonía. Pesado símbolo $(3,7,5)$, los invaluables objetos $(3,6,2)$ son un presente exigente que Alcmeón le da a Arsínoe $(3,7,5)$. Terminan en una sagrada consagración en Delfos. Una orden divina obedecida, los hijos de Alcmeón recogen colonizadores y colonizan Arcanania.

Diógenes Laercio reporta $(9,8)$ una declaración de Heráclito que reconoce un



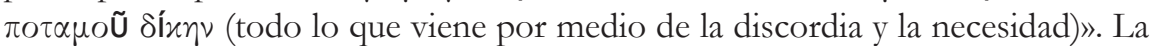
idea es reformulada siglos más tarde por Publilius Syrus quien, en el primer siglo a. C., adapta un proverbio que personaliza el concepto de necesidad. Su máxima 563 dice así: «La necesidad no conoce otra ley que la prevalecencia».

Aváysm es en efecto la diosa de la necesidad, el destino y la muerte. En la tradición griega órfica, ella es hija de Cronos y de la madre de Éter, Caos, Erekos. En la Republica de Platón (617), en competencia con Temis, es la madre de las Moiras (Átropos, Cloto, Láquesis), las comúnmente conocidas e impasibles Parcas que tejen el destino de cada ser humano, todos nosotros. Del orden cosmológico, Aváyren es la Madre necesaria. Y, del orden metafísico, es una Razón necesaria para el universo en todos sus aspectos. Debe lidiar con Nous, el dios de la inteligencia. Del recién mencionado artículo de Hillman, he aquí una clave para una lectura de la socio-historia del Mediterráneo; y, sin duda alguna, de la tensión entre el mito y la ciencia.

Pero ¿qué es la Necesidad? En búsqueda de respuestas a esta pregunta elaboraremos este punto importante: la necesidad en el pensamiento mitico griego es mencionada como una experiencia en modos patologizados. Las experiencias a menudo patologizadas están directamente conectadas con Ananke (Necesidad) (1980: 5).

\section{Conclusiones}

La mula, dice Susan Griffin en Woman and Nature (Harper y Row, 1980), trata de un signo de la otredad. Supongamos que es una de muchas imágenes del mundo de urbanidad. Una de las entradas a un idiolecto, promueve palabras y tareas, 
cuyos significados cruzados suscitan valores que movilizan bibliotecas y una agenda cósmica. Pongan entre paréntesis lo que significa la palabra, conéctenla con otras, despertando vacas, caballos, pájaros, otros seres, sugiere ella. Hay más que simples límites que abren vistas invisibles de círculos de vida infinitos, sus historias. Recorren el presente que aún no es, acortadas por la percepción del ayer. ¿No es un secreto del mundo que ordena sus mecánicas? Los umbrales visibles expresan lo que son. Las posibilidades de alcanzar el medio, aproximarse a lo invisible, entendiéndolo. Como cualquier otra cosa, sujeto, objetos y fines. En la mujer sin nombre de Ática obligada a jugar a ser Atena para dar la bienvenida a Pisístrato, los atenienses debían ver a la diosa, dice Heródoto $(1,60)$. Y lo hicieron. Martin Bernal cree que ella es, o puede ser idéntica a la Atena libia. Uno se estremece de enfrentar el teatro, sus riesgos por cruzar fronteras en el tiempo y el espacio. La invitación puede dilucidar una verdad enunciando estos pasajes: «la gracia del trabajo», esa «sobria belleza de la función de las cosas que son lo que son», «la definición, la línea, el movimiento» (2006:75). Griffin hace alusión a un ambiente. Y, amplificando etiquetas, ella se opone a lo que ellos suponen; $\mathrm{y}$, de esta manera, recrea un torrente de sentimientos por las fronteras reales y simbólicas. Las temáticas se refieren a la interpretación sobre las posibilidades de una inscripción en la fuerza de la materia. El «cómo sabemos» de su último capítulo resalta un sereno eje para una paternidad y una nueva generación de mujeres. La génesis se repite, una vez más. La existencia no puede sino renovar la materia en el cuerpo glorioso de una historia natural. Lo que ella narra es sobre una poética femenina del origen, la creación, la reproducción. Plantea una pregunta, y la única importante, existencialmente: ¿esta diferencia?

Sabemos que esta tierra está hecha de nuestros cuerpos. Pues nos vemos. Y somos naturaleza. Somos naturaleza que ve la naturaleza. Somos naturaleza con un concepto de naturaleza. [...] Naturaleza hablando de naturaleza a la naturaleza. El mirlo de alas rojas vuela en nosotros, en nuestra vista interna. Vemos el arco de su vuelo. Medimos la elipse. Predecimos su clímax (1980:226).

Primer punto: lo que está en riesgo, una manera de afirmar una acción en la comunión; en suma, saber como «nacer con», en lugar de «hacer y tener». Absortos en la traducción de las historias de otros, en los sentimientos de otras personas, como estudiante de crónicas en contraste con mitologías, ¿es uno que comprueba cuestiones válidas, admitiendo y acentuando razones que rigen las mentes y los cuerpos? Elogiosamente impuesto en las mentes, las teorías plantean o reimponen pasadas reverberaciones en el universo de las ideas y las ficciones. Monitorean los sentidos y lo que deberían desvelar. El solitario estudiante trata de narrar la belleza de las cosas de los textos, contemplaciones antiguas, jurisdicciones preconcebidas. No importa si Libia es hija de Épafo y Menfis, 
de Cronos y Rea, y tiene a Ío o Gea por abuela. Esa ciencia no es científica. Uno viene a transplantar sentimientos expresados anteriormente, efectos de leyendas bajo viejos diagramas mal juzgados, las mejores caricaturas de citaciones y máximas preelaboradas. La imitación inconsciente o calculada paradójicamente presta atención a una correcta transmisión de las maneras de percibir, de creer; en resumen, una ciencia sobre la vida y la muerte según paradigmas bien fundados. ¿Cómo reafirmar lo contrario de lo mismo, de las muy buenas leyes de autorepresentación y generación, y representar otro ángulo de compatibilidad?

¿Es Woman and Nature un mito como el de Libia, y las escabrosas historias sobre su descendencia? La realidad del Mediterráneo subsume su existencia «El rugido dentro de ella», subtítulo, dobla y desvela el peso de un pasado real, un texto. Esta es la presentación en la cubierta. Comienza, «sobre la memoria y la mutilación, ira femenina como poder, presencia femenina como fuerza transformadora». Libertad y proclama, «acoge el ritual y la ciencia, la historia y la imaginación, convocando las voces y el cuerpo de nuestra tierra y devolviéndonos el conocimiento de su belleza y de la nuestra», la presentación prosigue.

En una voz fundamental, de las lecturas de hoy a las de ayer, el testimonio de un viaje, uno después de miles, parece anular el significado de la mayoría de nuestros puntos de vista éticos, y muy específicamente sus principios de verificación. Aun así, a propósito del Mediterráneo, se reconstruyen a menudo en las confrontaciones de las disciplinas y las prácticas como si su calidad de ficciones no pudiera ser su propia explicación. Al final del segundo libro de su historia universal, Diodoro Sículo anuncia una decisión importante:





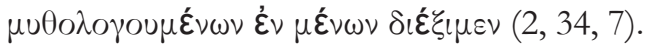

Con respecto a los reinos de los asirios y de los medos, y respecto a las diferencias en los relatos de los historiadores, consideramos que se ha dicho suficiente; ahora estudiaremos la India y luego, a su vez, relataremos de nuevo las leyendas de la tierra.

El final de la Bibliotheca, en el Epitome (8, 40), lo dice con elocuencia. La última línea habla de Ulises. «Fue a Etolia, a Toas, hijo de Andremón, desposó a la hija de Toas, y dejando un hijo Leontófono, a quien tuvo de ella, murió de edad avanzada». La historia, observa sir James G. Frazer en la última nota del libro: «No aparece mención de estas últimas obras registradas de Ulises en ningún otro autor antiguo».

¿Importa realmente? Posiblemente. 


\section{Bibliografía}

Barr, Stringfellow. 1968. A History of Greece from the Origins of Hellenic Culture to the death of Alexander, Philadelphia: J.P. Lippincott.

Barraclough, Geoffrey. 1984. The Times Atlas of World History, Maplewood, N.J.: HammondHammond.

Bell, Robert E. 1991. Women of Classical Mythology: A Biographical Dictionary, Oxford: Oxford University Press.

Benabou, M. 1976. La Résistance Áfricaine à la romanisation, Paris: Maspero.

Benveniste, Émile. 1973. Indo-Europaan Language and Society, Coral Gables, Florida: University of Miami Press.

Bernal, Martin. 2006. Black Athena: The Afroasiatic Roots of Classical Civilization. The Linguistic Evidence, New Brunswick, NJ: Rutgers University Press.

Bernal, Martin. 1991. Black Athena: The Afroasiatic Roots of Classical Civilization. The Archaeological and Documentary Evidence, New Brunswick, NJ: Rutgers University Press.

Bernal, Martin. 1987. Black Athena: The Afroasiatic Roots of Classical Civilization. The Fabrication of Ancient Greece 1785-1985, New Brunswick, NJ: Rutgers University Press.

Bode, Georg Heinrich. 1968. Scriptores rerum mythicarum Latini tres Romae nuper reperti. Edidit ac scholiis illustravit Georgius Henricus Bode. Hildesheim: G. Olms.

Bradford, Ernle. 1971. Mediterranean Portrait of A Sea, New York: Harcourt.

Bradley, Guy y John-Paul Wilson. 2006. Greek and Roman Colonization, Swansea: The Classical Press of Wales.

Braudel, Fernand. 1998. Les mémoires de la Méditerranée prébistoire, París: Éditions de Fallois. Bourgeois, Alain. 1970. La Grèce antique devant la négritude, Paris: Présence Africaine.

Bremmer, J. (ed.). 1987. Interpretations of Greek Mythology, Londres: Thames and Hudson.

Burke, Peter. 1992. New Perspectives on History. University Park, PA: Pennsylvania State University Press.

Cahill, Thomas. 2003. Sailing the Wine-Dark Sea: Why the Greeks Matter. New York, Doubleday.

Ceram, C.W. 1949. Götter, Gräber und Gelehrte, Rowohlt Verlag Gmblt: Hamburg-Stuttgart.

Ceram, C.W. 1951. Gods, Graves and Scholars, New York: Alfred A. Knopf.

Chantraine, Pierre. 2000. Dictionnaire étymologique de la langue grecque, París: Klincksieck.

Chastaing, Maxime, 1951. L'Existence des autres, Paris: Presses Universitaires de France.

Claudio Ptolomeo. 2000. Geography, Princeton: Princeton University Press.

Tabula Rasa. Bogotá - Colombia, No.11: 141-193, julio-diciembre 2009

ISSN 1794-2489

190 
Combats pour un Christianisme Áfricain. 1980. Facultad de Teología Católica, Kinshasa.

Colin McEvedy. 2002. The New Penguin Atlas of Ancient History, New York: Penguin.

Diels, H. 1929. Doxographi Graeci, Berlin: de Gruyter.

Diop, Cheik Anta. 1991. Civilization or Barbarism: An Authentic Anthropology, New York: Lawrence Hill.

Dodds, E.R. 1951. The Greeks and the Irrational, Berkeley: University of California Press.

Dray, William. 1957. Laws and Explanation in History, Oxford: Oxford University Press.

Ehrenberg, Victor. 1968. From Solon to Socrates: Greek History and Civilization, Londres: Methuen.

Estienne, H. 1954. Thesaurus Graecae Linguae, París: Graz.

Forcellini, A. 1940. Totius Latinitatis Lexicon. S.D.

Frazer, Sir James G. 1922. The Golden Bough, Londres: MacMillan.

Goldhill, Simon. 2002. Who Needs Greek? Cambridge: Cambridge University Press.

Grant, Michael. 1995. Greek and Roman Historians: Information and Misinformation, Londres: Routledge.

Griffin, Susan. 1980. Woman and Nature, New York: Harper \& Row.

Grimal, Pierre. 1985. Dictionary of Classical Mythology, Oxford: Blackwell.

Grun, Bernard. 1975. The Timetables of History, Londres: Thames \& Hudson.

Hempel, Carl G. 1974. "reasons and covering laws", en The Philosophy of History, Patrick Gardiner (ed.). Londres: Oxford University Press.

Hillman, James. 1980. Facing the Gods, Dallas, Tex: Spring Publications Inc.

Irigaray, Luce. 2002. To Speak is Never Neutral, New York: Routledge.

James, Peter. 1993. Centuries of Darkness: A Challenge to the Conventional Chronology of Old World Archaeology. New Brunswick, NJ: Rutgers University Press.

Jung, C.G. 1974. Mysterium Coniunctionis, Princetyon, NJ: Princeton University Press.

Keller, Werner. 1956. The Bible as History, Londres: Hodder \& Stoughton.

Knapp, A. Bernard. 1988. The History and Culture of Ancient Western Asia and Egypt, Chicago: Dorsey Press.

Lesky, Albin. 1966. A History of Greek Literature, New York: Hackett.

Lévi-Strauss, Claude. 1974. Structural Anthropology. New York: Basic Books.

May, E.R. 1973. "Lessons" from the Past, New York: Oxford University Press. 
McEvedy, Colin. 2002. The New Penguin Atlas of the Ancient World, New York: Penguin.

Mercier, E. 1895. Recueil des Notices et Mémoires de la société archéologique de Constantine.

Morford, Mark P.O. y Robert J. Lenardon. 1995. Classical Mythology. New York: Longman.

Müller, K. 1841-1869. Fragmenta Historicorum Graecorum, París: A. F. Dido.

Mveng, Engelbert. 1972. Les Sources grecques de l'histoire négro-africaine depuis Homère jusqu'a Strabon, Paris: Présence Africaine.

Obenga, Théophile. 1990. La Philosophie Áfricaine de la période pharaonique 2780-339 avant nôtre ère, París: L'Harmattan.

Paulys-Wissoua-Kroll. 1837. Reäl Encyclopädie der Klassichen Altertumswissenschaft, Stuttgart: J. B. Metzler.

Paton, W.R. (ed.). 1916. The Greek Anthology, Loeb Classical Library; Londres: William Heinemann.

Poe, Richard. 1999. Black Spark, White Fire: Did African Explorers Civilize Ancient Europe? New York: Prima, Random.

Pressfield, Steven. 2002. The Last of the Amazons, New York: Doubleday.

Price, Simon y Emily Kearns. 2003. The Oxford Dictionary of Classical Myth and Religion, Oxford: Oxford University Press.

Ramin, J. 1979. Mythologie et géographie, Paris: Les Belles Lettres.

Renfrew, Colin. 1993. "Foreword" en Centuries of Darkness: A Challenge to the Conventional Chronology of Old World Archaeology. James, Peter. New Brunswick, NJ: Rutgers University Press.

Rey, Abel. 1936. La Science hellénistique. París: La Renaissance du livre.

Rey, Abel. 1933. La Jeunesse de la science grecque, París: La Renaissance du livre.

Rey, Abel. 1930. La Science orientale avant les Grecs, París: La Renaissance du livre.

Rose, H.J. 1928. Handbook of Greek mythology : including its extension to Rome, London: Methuen \& Co.

Sissa, Giulia y Marcel Detienne. 2000. The Daily Life of the Greek Gods, Stanford: Stanford University Press.

Snowden, Frank M. 1971. Blacks in Antiquity: Ethiopians in the Greco-Roman Experience. Cambridge: Belknap Press.

Steins, Werner. 1979. Kultur Fahrplan, New York: Simon \& Schuster.

Toutain, J. 1927. L'économie antique, Paris: La Renaissance du Livre.

Vernant, Jean-Pierre. 2001. The Universe, Gods and Men, New York: Harper-Colllins. 
TABULA RASA

No.11, julio-diciembre de 2009

Veyne, Paul. 1988. Did the Greeks Believe in their Myths? Chicago: The University of Chicago Press.

Veyne, Paul. 1984. Writing History, Middletown, Connecticut: Wesleyan University Press.

Westermann, A. 1843. Scriptores Poeticae Historiae Graeci, Berlín: Brunsvigae.

Winstone, HVF. 1986. Uncovering the Ancient World, New York: Facts on File Publications.

Autores griegos y latinos consultados en la Loeb Classical Library:

Arquíloco

Apolodoro de Atenas

Apolonio de Rodas

Aristóteles

Esopo.

Esquilo,

Estesícoro

Eurípides,

Dío Casio

Dión Crisóstomo

Dionisio de Halicarnaso

Diodoro Sículo

Filóstrato el Ateniense.

Homero

Heródoto Herodoto

Hesíodo

Parsanias

Píndaro

Plinio El Viejo

Platón

Sófocles

Strabo

Tucídides

Varro 